\title{
From Detection to Intervention Psychological Aspects of Online Hearing Rehabilitation
}

Peter Molander

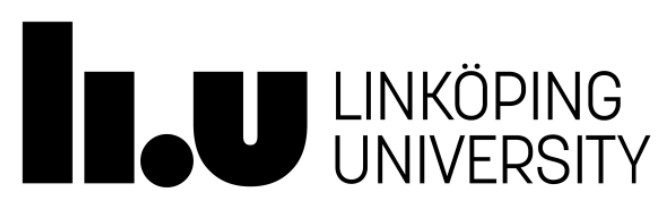

Linköping Studies in Arts and Science No. 751

Studies from the Swedish Institute for Disability Research • No. 92

Linköping 2018 
Linköping Studies in Arts and Science $\cdot$ No. 751

Studies from the Swedish Institute for Disability Research • No. 92

At the Faculty of Arts and Sciences at Linköping University, research and doctoral studies are carried out within broad problem areas. Research is organized in interdisciplinary research environments and doctoral studies mainly in graduate schools. Jointly, they publish the series Linköping Studies in Arts and Science. This thesis comes from the Swedish Institute for Disability Research at the Department of Behavioural Sciences.

Distributed by:

Department of Behavioural Sciences and Learning

Linköping University

58183 Linköping

Peter Molander

From Detection to Intervention

Psychological Aspects of Online Hearing Rehabilitation

Edition 1:1

ISBN 978-91-7685-226-2

ISSN 0282-9800

ISSN 1650-1128

(C) Peter Molander

Department of Behavioural Sciences and Learning, 2018

Printed by: LiU-tryck, Linköping 2018 
Science makes me feel stupid too. It's just that I've gotten used to it.

Schwartz, M. (2008). p. 1771 


\section{Abstract}

Hearing problems are among the most common causes of disability worldwide for adults. It is currently classified as one of the top five causes of years lived with disability (YLD), affecting more than half a billion people, and the problem seems to be growing. Between the years 2005 and 2015 the global period prevalence of hearing loss increased with about $26 \%$. The negative impact of hearing loss on those affected is not limited only to communication problems. A range of other negative effects can be present, such as increased levels of social isolation, problems in the work-place and psychological distress.

Even though there are established - and in most of the developed world - accessible ways for people with hearing loss to seek professional care, a substantial number does not seek it. Some authors report a typical wait-time of around 10 years for people to go from noticing a hearing problem to seeking help. One way of addressing this issue might be to make it easy for people to screen for hearing loss over the internet. Another way of using the internet to further help people with hearing loss is to offer treatment for comorbid psychological distress online.

The different studies of the thesis can be summarized in three overall research questions. First, can hearing loss be detected through automated online screening procedures, and what are the characteristics of those who participate (Study I and II)? Second, can psychological acceptance be measured in this population using a new questionnaire (Study III)? Finally, can online administered self-help based on Acceptance and Commitment Therapy $[\mathrm{ACT}]$ help persons with hearing loss and psychological distress (Study IV)?

In the screening studies (Study I and II) an online speech-innoise hearing test was initially developed and later updated. Screening for hearing problems with this test was feasible, and 16.7 (Study I) -19\% (Study II) of the participants were recommended to seek professional care for their potential hearing loss. These participants had more cognitive problems, were more often men than women, and had lower levels of education. There were no differences on measures of depression, anxiety or quality of life. In Study III, we found that it was possible to accurately measure hearing-related acceptance with a new questionnaire and found that this measure was a better predictor of hearing-related disability than measured hearing performance. In 
Study IV, people with hearing loss and comorbid psychological distress were offered an eight-week long internet-based therapist-guided self-help influenced by ACT. When comparing those who received treatment to those in the wait-list control group, the treatment group had lower levels of perceived hearing disability, increased quality of life and reduced depressive symptoms.

In conclusion, hearing screening can be performed online and it is possible to measure hearing-related factors such as cognition in these procedures. Further, lack of hearing-related acceptance can be measured with a questionnaire and this seems to be an important facet of the impact of hearing on health. Further, an internet-based ACT approach can help those with psychological distress and hearing loss. 


\section{Empirical studies}

Study I. Molander, P., Nordqvist, P., Öberg, M., Lunner, T., Lyxell, B., \& Andersson, G. (2013). Internet-based hearing screening using speech-innoise: validation and comparisons of self-reported hearing problems, quality of life and phonological representation. BMJ Open, 3(9), e003223.

Study II. Molander, P., Nordqvist, P., Ellis, R., Rönnberg, J., Lyxell, B., Dahlström, Ö., Lunner, T., \& Andersson, G. (2018). Online administration of a speech-in-noise test and its relationship to hearing problems, cognition and psychological distress. Manuscript submitted for publication.

Study III. Molander, P., Andersson, G., \& Hesser, H. (2018). Measuring psychological acceptance of hearing loss - psychometric evaluation and validation of the hearing acceptance questionnaire. Manuscript submitted for publication.

Study IV. Molander, P., Hesser, H., Weineland, S., Bergwall, K., Buck, S., Jäder Malmlöf, J., Lantz, H., Lunner, T., \& Andersson, G. (2018). Internetbased acceptance and commitment therapy for psychological distress experienced by people with hearing problems: a pilot randomized controlled trial. Cognitive Behaviour Therapy, 47, 169-184. 


\section{Table of contents}

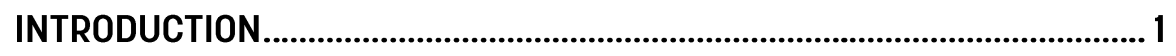

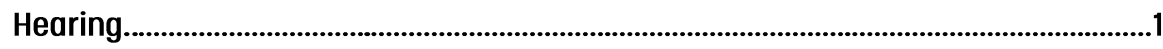

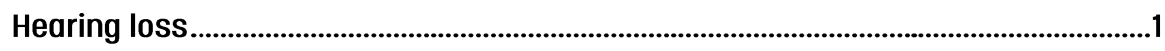

Prevalence ......................................................................................................................................................

Screening for hearing loss ....................................................................................................................

Issues in detection and rehabilitation.............................................................................................

Psychological aspects of hearing loss.......................................................................9

Hearing and cognition ...........................................................................................................................11

Hearing and acceptance...............................................................................................................13

Hearing and experiential avoidance ......................................................................................................16

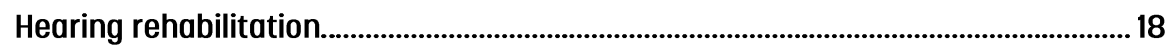

Psychological and behavioural interventions in audiology .................................................19

Internet delivered treatments............................................................................................................ 21

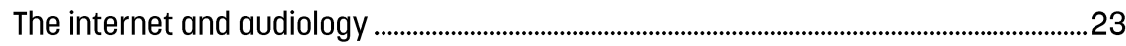

Thesis in context ..................................................................................................................

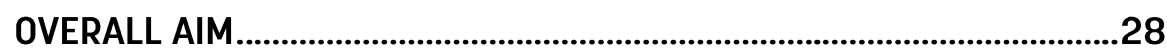

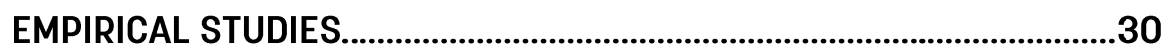

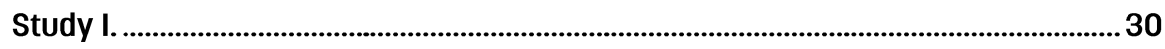

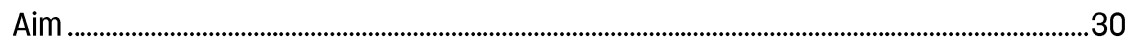

Methods .................................................................................................................................................

Results and discussion ............................................................................................................

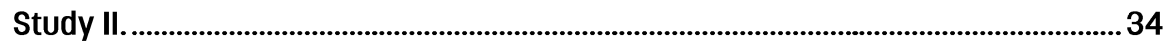

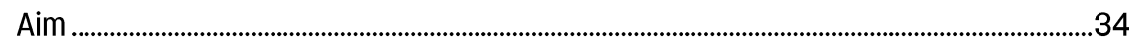

Methods................................................................................................................................................34

Results and discussion .................................................................................................................................

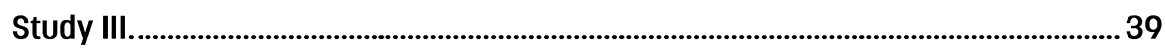

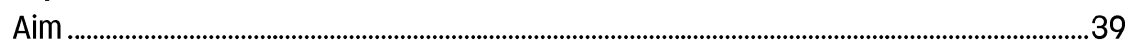

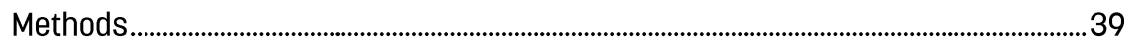




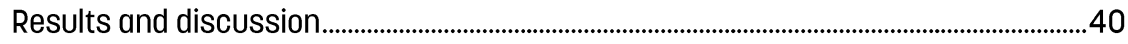

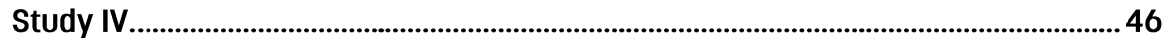

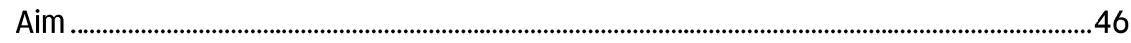

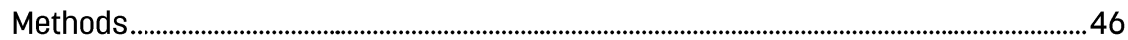

Results and discussion....................................................................................................................48

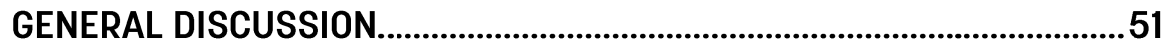

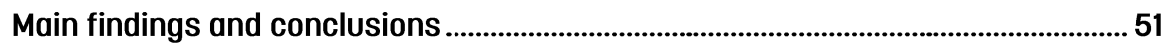

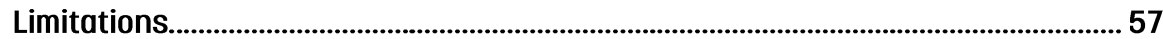

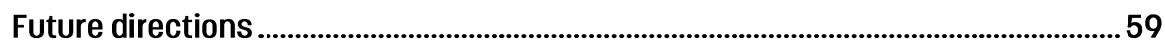

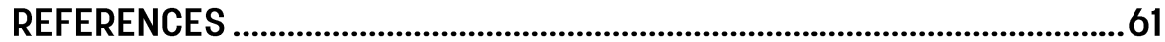

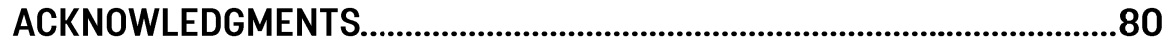

STUDIES FROM THE SWEDISH INSTITUTE FOR DISABILITY RESEARCH 


\section{Introduction}

\section{Hearing}

The auditory system provides meaningful information about the world around us. It detects, encodes and analyses sound, which allows us to identify and understand the meaning of different auditory signals (Plack, 2010). By doing so, it enables humans to engage in verbal communication, which is important for most people. Beyond the role of hearing in enabling people to communicate with each other, participate in activities and experience the surroundings, the hearing sense is also of importance for one's safety. It probably evolved partly through its usefulness for detection of both predators and prey (Fay \& Popper, 2000). Hearing in the modern world makes it possible to perceive warning shouts, sirens or traffic noise (Wallhagen, 2010). Therefore, hearing problems can have a serious negative impact on those affected. It is very common to perceive hearing problems, and hearing problems can be thought of as a continuous variable where most people, at least in some situations, have difficulties (Cardon \& Sharma, 2018). For example, people with a clinically established normal hearing ability can still have a hard time communicating in places like noisy restaurants (Ruggles, Bharadwaj, \& Shinn-Cunningham, 2011).

\section{Hearing loss}

Hearing loss is one of the most common causes of disability worldwide for adults. It is currently classified as one of the top five causes of years lived with disability (YLD), affecting more than half a billion people, and the problem seems to be growing (Vos et al., 2016; Wilson, Tucci, Merson, \& O’Donoghue, 2017). Typically, hearing loss becomes evident when hearing in everyday life is no longer functioning as one is used to (Elberling \& Worsöe, 2006). Common examples include miscommunications, being unable to hear sounds from nature such as birds singing, or having a hard time noticing when the doorbell rings.

An established categorization of common types of hearing loss are that they either are conductive, where transmission of sound to the inner ear is hampered, or sensorineural, where usually the hair cells of the inner ear is 
affected, or finally central where there is no apparent abnormality in the peripheral auditory system but problems instead arise in processing auditory information in the central nervous system (Gelfand, 2009; Zeng \& Djalilian, 2010). Difficulties with hearing is part of the ageing process for most mammals (Yamasoba et al., 2013). Interestingly, already from very early stages of hearing loss there is evidence that mechanisms of neural plasticity that try to compensate for the shortcomings of the auditory system by engaging other sensory-related cortical areas (Cardon \& Sharma, 2018).

Hearing loss is usually classified after severity as mild, moderate, or severe (Gelfand, 2009). Further, there are varying definitions and labels to describe hearing loss that convey different aspects of the phenomenon (such as deafness, deafened, hard of hearing, hearing disability, or hearing impairment) (Manchaiah \& Stephens, 2013). In the present thesis the term hearing loss will be used in a broad sense to describe an individual's problem with hearing rather than more specific descriptors unless another term is specifically used in the referenced publication.

Regardless of terminology, the negative impact of hearing loss on those affected is not limited to communication problems. A range of other negative effects can occur. For example, people with hearing loss have an even harder time to keep up with conversation in adverse listening conditions, and have to exert extra effort to deal with the increased cognitive load in such situations (Hopkins, Moore, \& Stone, 2008; Plomp, 1986; Rönnberg et al., 2013). Such an increased effort can then be used to explain why people with hearing loss can feel fatigued, have an increased need for recovery after work, and have issues with remaining occupationally active (Gustafsson et al., 2011; Nachtegaal et al., 2009; Nachtegaal, Festen, \& Kramer, 2011). Hearing loss is also associated with social isolation and psychological distress (Demorest \& Erdman, 1986; Strawbridge, Wallhagen, Shema, \& Kaplan, 2000). Further, hearing loss seem to increase the risk of dementia (Livingston et al., 2017). Also, those with hearing loss have increased rates of tinnitus and hyperacusis which both are conditions that might negatively impact the psychological well-being of those affected (Jüris, Andersson, Larsen, \& Ekselius, 2014; Krog, Engdahl, \& Tambs, 2010). 


\section{Prevalence}

Between the years 2005 and 2015 the global prevalence of hearing loss increased with about $26 \%$. Much of this increase can be attributed to an overall ageing population, as most of hearing loss is of the variant associated with old age. However, all the increase seems not to be only caused by age (Vos et al., 2016). A few percent of people in the age groups between 20 and 29 meet criteria for hearing loss. For example, Agrawal and colleagues reported that $3.1 \%$ of this age strata had speech frequency hearing loss and $8.5 \%$ had higher frequency hearing loss in a US sample (2013).

Although the global prevalence seems to be increasing, recent research indicates that the same trend is not necessarily observable in Sweden. For example, when examining mostly males who underwent pure tone audiometric testing as a part of compulsory conscription examination between 1971 and 2010 rates of hearing impairment showed a decreasing trend from $6.7 \%$ to $2.5 \%$ of hearing loss $>35 \mathrm{~dB}$ HL (Muhr, Johnson, \& Rosenhall, 2017). The same trend was observed for the elderly. When examining a new cohort of 70-year old participants in three previous cohorts, measured when at the same age, born in 1901-02, 1906-07 and 1922, both men and women in the new cohort showed improved hearing. The prevalence for women went from $37 \%$ to $23 \%$, and for men from $53 \%$ to $28 \%$ (Hoff, Tengstrand, Sadeghi, Skoog, \& Rosenhall, 2018). The decreased prevalence for men is probably because of a decrease in occupational noise exposure. However, considering an ageing population, the overall prevalence seems to be rising and about $18.3 \%$ of the Swedish population currently have hearing loss (SCB, 2017).

Overall, the established trend among older studies on the field of gender differences in hearing have concluded that although hearing ability vary greatly between individuals across gender and age, men tend to have greater decline of hearing ability from their 30's than women (Morrell, GordonSalant, Pearson, Brant, \& Fozard, 1996; Pearson et al., 1995). Newer research contradicts those finding and find no evidence for the negative slopes of increasing difficulty in verbal communication by age and time (Pronk et al., 2013; Stam et al., 2015). Regardless of gender, most cases of hearing loss go without diagnosis or intervention (Kochkin, 2007). 
Although rates of decline might not be that different, absolute differences seem to exist in Sweden, with $23 \%$ of Swedish 70-year old women suffering from hearing loss while $28 \%$ of men are affected (Hoff, Tengstrand, Sadeghi, Skoog, \& Rosenhall, 2018). The impact of hearing loss on one's quality of life and ability to participate in society to a desired level might also affect men and women differently. In one study, women in their 60's with hearing loss reported more social isolation than men with similar levels of hearing loss (Mick, Kawachi, \& Lin, 2014). Another study found that women with hearing problems scored higher on a measure of depression symptoms than men, irrespective of age (Keidser, Seeto, Rudner, Hygge, \& Rönnberg, 2015). However, some studies also suggest that women are better at allocating cognitive resources to understand verbal communication, leading to the observation that women seem to be better at speech-reading than men as a way of compensating for a decline in hearing ability (Phillips, Lowe, Lurito, Dzemidzic, \& Mathews, 2001; Strelnikov et al., 2009).

Other differences appear in how hearing loss is managed in health care. Fitting hearing aids in both ears is often recommended (Byrne, 1981; Jespersen, Groth, Kiessling, Brenner, \& Jensen, 2006), and in the Swedish Quality Register for Hearing Aids, binaural fitting is associated with greater hearing aid benefit (Forskningsinstitutet Hörselbron, 2012). Despite this, in a report from the Swedish Hard of Hearing Association, it was revealed that in certain county councils women were far less likely to get hearing aids in both ears than men (Hörselskadades Riksförbund, 2017).

When considering that the relative numbers of people affected by hearing problems for certain age groups in Sweden might be declining, the absolute number in the total population is still quite large. For example, when only counting those with a diagnosed condition and a willingness to undertake rehabilitation, over 200000 patients had an hearing aid fitted in Sweden between the years 2012 and 2016 (Arlinger, Nordqvist, \& Öberg, 2017). With such a great number of people being affected, there is an obvious need of efficient ways of offering rehabilitation. Before any rehabilitation can start, an actual case of hearing loss must be detected and classified. For this 
purpose, several different ways of offering screening procedures have been launched in the last few decades.

\section{Screening for hearing loss}

There is a need to increase access to hearing rehabilitation (Nieman \& Lin, 2017). One step in that direction is through screening. Screening programs are procedures developed to detect health problems through testing of certain populations. The idea is not new as programs for testing for syphilis and tuberculosis started already in the beginning of the last century (Harris, Sawaya, Moyer, \& Calonge, 2011). Simply being able to test for something is however not enough for a successful screening program. In 1968, the World Health Organization published a set of principles for screening programs, where at least ten criteria should be considered (Wilson \& Jungner, 1968). For example, there should be a treatment for the condition, there should be facilities for diagnosis and treatment, the test should be acceptable in the population, and the cost of finding a case should be economically defensible. In the case of screening for hearing loss, there are several ways to launch a screening program of reasonable quality.

The gold-standard for assessing hearing ability is to test a person's ability to detect pure tones for their best hearing ear at a range of frequencies (usually $0.5,1,2$, and $4 \mathrm{kHz}$ ), sitting inside a quiet room (Kiely, Gopinath, Mitchell, Browning, \& Anstey, 2012). It also recommended that the clinician collect a detailed case history. Beyond pure-tone audiometry [PTA], tests of speech reception in noise and other psychoacoustic evaluations can be used (Gelfand, 2009). Even though parts of the PTA process sometimes can be more or less automated, it still is quite demanding when it comes to setting, staff and equipment when used as a screening tool. It is therefore more often used in a later stage of the rehabilitation process for diagnostic purposes. However, some screening studies have used real life PTA-tests (such as Yueh et al., 2010).

Instead, the most common test for objective hearing performance in screening programs is some form of speech in noise test, which makes it possible to detect sensorineural hearing loss. Often, this takes the form of numbers spoken in varying degrees of background noise, where a correct answer 
increases the difficulty in the next task by increasing the amount of background noise thus making speech intelligibility harder. This method was used in the HearCom project, where such tests were developed for used in different languages funded by a grant from the European Union (Smits, Merkus, \& Houtgast, 2006; Vlaming \& Houtgast, 2010). These tests are often fully-automated and disseminated through telephone, smartphone or computer. Their results usually correlates well with the ability to perceive spoken language in noisy environments, which is one of the most common complaints among those with hearing loss (Heinrich, Henshaw, \& Ferguson, 2015; Swanepoel \& Hall, 2010; Theunissen, Swanepoel, \& Hanekom, 2009).

Another form of screening for hearing loss is through subjective assessments of hearing ability. Usually this is done using validated questionnaires. Some researchers have investigated if questionnaires are needed, or if just asking the participants if they believe that they have significant hearing loss or not renders similar results. This method of using a single item has sometimes been surprisingly efficient, with one study of Finnish people aged 70 over older finding a sensitivity of $100 \%$ and a specificity of $70.7 \%$ for moderate or worse hearing loss in relation to PTA (Salonen, Johansson, Karjalainen, Vahlberg, \& Isoaho, 2011). This meant that it performed better than an established questionnaire, the Hearing Handicap Inventory for the Elderly [HHIE]. However, in another study the use of a questionnaire, the Speech, Spatial and Qualities of Hearing Scale -5 [SSQ5], outperformed the use of a single question (Demeester et al., 2012). Some authors argue against the use of self-report altogether, as this approach risk over-estimating cases of hearing loss among young people while under-estimating prevalence among the elderly (Kiely et al., 2012).

Another popular questionnaire for assessing perceived hearing difficulties is the Amsterdam Inventory for Auditory Disability and Handicap [AIADH] (Kramer, Kapteyn, Festen, \& Tobi, 1996). This instrument is sometimes used for diagnostic purposes at hearing aid dispensers (Boeschen Hospers et al., 2016). It is also part of the internet-based "Netherlands Longitudinal Study on Hearing", which is an add-on to the National Hearing test that uses a speech-in-noise test with digits spoken in varying amounts of background noise online or through telephone (Nachtegaal et al., 2009). Overall, 
completing a questionnaire as a measure of hearing screening is the preferred option of those with potential hearing problems, above more objective measures, because of a perceived higher reliability (Koopman, Davey, Thomas, Wittkop, \& Verschuure, 2008).

Another important aspect, beyond what kind of test that has the best sensitivity/specificity or is the most attractive option for those with potential hearing loss, is what kind of screening procedure leads to a successful rehabilitation. Far from everyone who fail a screening procedure seeks help. For example, although $46 \%$ of participants failed a screening with both PTA and questionnaires, only $18 \%$ actually tried using a hearing aid and only 11 $\%$ were using a hearing aid 2 years later (Meyer, Hickson, Khan, \& Hartley, 2011; Thodi et al., 2013). In a literature review, the only factor positively affecting long term outcomes was self-reported hearing disability (Knudsen, Öberg, Nielsen, Naylor, \& Kramer, 2010).

To summarize, there are at least three discernible methods for hearing screening programs. First there is objective testing with specialized equipment, sometimes in conjunction with questionnaires, that renders the most reliable diagnostic results (Thodi et al., 2013; Yueh et al., 2010). Second, there are automated speech in noise tests delivered through computer, smartphone or telephone (Potgieter, Swanepoel, Myburgh, Hopper, \& Smits, 2016; Smits et al., 2006), which is easier and cheaper to disseminate while still being reasonably reliable. Finally, there are measures of subjective hearing performance (Demeester et al., 2012). These are sometimes valid and reliable, and the best predictors of subsequent rehabilitation.

In this thesis, both screening studies (Study I and Study II), used speech in noise tests combined with both questionnaire and single questions of hearing disability.

\section{Issues in detection and rehabilitation}

Even though there are accurate, and in most of the developed world, accessible ways for people with hearing loss to seek professional care, a staggering number does not seek it. Some authors report a typical wait-time of around ten years for people to go from noticing a hearing problem to 
seeking help (Davis, Smith, Ferguson, Stephens, \& Gianopoulos, 2007). One estimate was that four out of five individuals, in the age span of 55-74 year, who would benefit from a hearing aid do not use one (McCormack \& Fortnum, 2013).

One reason for delaying help-seeking is that some people attach a stigma to both hearing loss and the use of hearing aids (Wallhagen, 2010). As people with hearing loss can regarded cognitively impaired, socially incompetent and overall lesser abled, those with untreated hearing loss seem to avoid being associated with these negative traits (Southall, Gagné, \& Jennings, 2010). Seeking help or having a hearing aid fitted can also be a source of having to alter one's self-perception as someone with a disability. Other obstacles are related to feeling older and to risk being seen as less attractive (Wallhagen, 2010).

When finally getting a diagnosis and hearing aids another problem arises which is that many owners of hearing aids do not wear them at all or only wear them occasionally. For example, in one study $24 \%$ of hearing aid owners reported that they never used them (Hartley, Rochtchina, Newall, Golding, \& Mitchell, 2010). Although other studies have found lower rates of non-usage, especially when examining more modern digital hearing aids, the general pattern is that many recipients do not utilize their devices (McCormack \& Fortnum, 2013). It is however important to remember that the general trend seem to be that hearing aid owners nowadays are more pleased with their devices than previously (Kochkin, 2010). Beyond stigmawhich is a bigger issue for younger hearing aid owners-common reasons for not using a hearing aid is finding that is not useful, lack of comfort, problems handling the device, and not perceiving any benefit in noisy situations.

Interestingly, how satisfied hearing aid users are seem not to primarily be driven by hearing threshold levels but rather by being a more experienced hearing aid user rather than being a novel user (Arlinger et al., 2017). Having two hearing aids, a bilateral fitting, is also associated with higher hearing aid satisfaction. Of course, one reason for this could be that fitting two hearing aids occur more often amongst those with more severe bilateral hearing loss, 
which in turn would mean that there is more room for improvement in this group.

These results indicate that many people need to have longer durations of hearing loss in order to move from detection, diagnosis, rehabilitation and finally reaching a certain level of satisfaction. One way of describing this phenomenon is through the use of a so called patient journey model (Manchaiah \& Stephens, 2012). By summarizing how people with hearing loss themselves described their experiences, a model with 7 separate phases emerged: pre-awareness, awareness, movement, diagnostics, rehabilitation, self-evaluation, and finally resolution (Manchaiah, Stephens, \& Meredith, 2011).

The fact that both pre-awareness and awareness were stages that those with hearing loss themselves emphasized as pivotal dovetails nicely with previous research. For instance, it is rather common that relatives are the first to notice a diminished hearing ability before the affected persons themselves do (Meyer et al., 2011). For many people to go through the awareness phase for a long period is also supported by earlier studies. For instance, Southall (2010) found that for people to do something about their hearing they have to research certain 'critical junctures'. This meant only recognizing the issue after building up negative emotions that abruptly intensified the need to seek help. Further, when possible positive effects of getting help outweighed the perceived drawbacks of being identified as someone with hearing problems help seeking could begin.

\section{Psychological aspects of hearing loss}

As mentioned earlier, the negative impact of hearing loss is not restricted to only communication problems or problems for persons who are occupationally active. The general quality of life overall is lower among people with hearing loss (Nordvik et al., 2018). Many of those affected also experience increased levels of anxiety (Chung, Hung, Lin, \& Sheu, 2015; Jones, Victor, \& Vetter, 1984). This effect is more pronounced in younger people with hearing loss (Tambs, 2004). The trend is that when hearing loss 
becomes more severe, the levels of anxiety also increases (Contrera et al., 2017).

Depressive symptoms are also more common among individuals with hearing loss, with more hearing loss being associated with more severe depression (Keidser \& Seeto, 2017; Janneke Nachtegaal et al., 2009). Although anxiety and depression is common, a study on patients in a Swedish quality registry found that few received any treatment or any extended rehabilitation to address these health issues (Carlsson et al., 2014). The interplay between depressive symptoms and hearing was further studied in the work by Keidser and Seeto (2017). They explored how hearing ability and various psychosocial variables and age interacted in a dataset known as the UK Biobank that contains more than 130000 participants. Even when accounting for the effects of physical illness, social isolation and unemployment, poor hearing was associated with both more depressive symptoms and more frequent depressive episodes. The authors concluded that audiological services also should consider offering psychosocial interventions.

A commonly suggested pathway between hearing loss and depression is the observation that as people with hearing loss seem to isolate themselves from social interactions (Strawbridge, Wallhagen, Shema, \& Kaplan, 2000). This is thought to be because hearing loss makes communication difficult, and thus makes social interactions harder and less rewarding. The social isolation then creates feelings of loneliness and depression (Mick et al., 2014; Ventry \& Weinstein, 1982).

Another factor that might make people with hearing loss less inclined to engage in social activities is feeling tired or fatigued. For example, people with hearing loss have increased need of recovery after work, even when controlling for job characteristics (Nachtegaal et al., 2009). Some studies imply that people with hearing loss need to exert more effort to listen (Hornsby, 2013; Picou, Ricketts, \& Hornsby, 2013). Indeed, a recent consensus statement proposed a new framework for understanding the mental energy needed for successful listening; a Framework for Understanding Effortful Listening [FUEL] (Pichora-Fuller et al., 2016). This model 
incorporates both a view on cognitive capacity as limited by supply as well as how motivation in different situations might impact hearing ability.

Most of the negative psychological and social consequences of hearing loss are more pronounced in younger people (Keidser, Seeto, Rudner, Hygge, \& Rönnberg, 2015; Nachtegaal et al., 2009). The reason for this is unknown, but it might be the case that it is more socially accepted for older people to have hearing loss, meaning that less stigma is attached to hearing loss among the elderly.

\section{Hearing and cognition}

One potential reason for people to delay help seeking for hearing loss could be cognitive functioning. One study found that participants with better reasoning ability were less likely to adopt hearing aids (Meyer, Hickson, Lovelock, Lampert, \& Khan, 2014). It could be that problem-solving skills are related to being better use of communication strategies, and thus less perceived need for a hearing aid.

Another way that cognitive ability is of importance for hearing loss is through the emergence of cognitive hearing science (Arlinger, Lunner, Lyxell, \& Pichora-Fuller, 2009). This field studies interactions between hearing ability and cognitive capacity. Especially two different cognitive factors have received attention as important for hearing ability; working memory, and to a lesser degree phonological awareness (Rönnberg et al., 2016). Although several cognitive abilities are related to hearing, the exact mechanisms are not yet well understood (Harrison Bush, Lister, Lin, Betz, \& Edwards, 2015). Ten years ago, Akeroyd (2008) reviewed 20 studies on the relationship between cognition and hearing and concluded that even though there is a link between cognition and hearing, there is not one single test that is a robust predictor of this effect. He also noticed that general tests, such as those of global IQ, performed the worst whereas specific tests - and especially test of working memory - seemed to do better.

Working memory capacity is of relevance for hearing loss for several reasons. For example, recent research with high quality measures and large sample sizes, has shown that working memory capacity is negatively related to 
hearing (Rönnberg, Hygge, Keidser, \& Rudner, 2014). This relationship is important when trying to perceive speech in challenging conditions (Tao \& Taft, 2017; Wingfield \& Tun, 2007). However, not all studies can replicate this effect for a range of cognitive abilities, including working memory in more experimental and controlled settings (Nuesse, Steenken, Neher, \& Holube, 2018).

One of the most prominent theories of the likely relationship between hearing and cognition is the Ease of Language Understanding model [ELU] model (Rönnberg et al., 2013). In this model, working memory is involved in both storing and processing of information. When spoken stimuli is ambiguous, and automatic matching of the signal with phonological representation in the long-term memory fails, working memory capacity can facilitate understanding by actively matching the correct word based on the available information through explicit processing (Rönnberg, 2003). Working memory can also serve to provide contextual information that facilitates understanding. Further, processing speed in one's working memory capacity is also of importance as higher speed allows to keep up in conversations.

The role of working memory is even more important among people who use hearing aids. A large body of research has shown that working memory capacity influences hearing aid benefit (Gatehouse, Naylor, \& Elberling, 2006; Lunner, 2003; Pichora-Fuller \& Singh, 2006). Modern hearing aids are not only capable of amplifying sounds but also enhance speech, suppress noise and keep loudness levels comfortable (Souza, Arehart, \& Neher, 2015). Depending on the working memory capacity, different amounts of signal alterations seem to be useful, where people with high working memory seem to benefit from fast compression - perhaps by being able to distinguish between mere artefacts and helpful information.

Phonological awareness has received less attention than working memory in studies on cognitive models of hearing, but there is a fair amount of research highlighting its importance (Andersson \& Lyxell, 1998; Classon, Rudner, \& Rönnberg, 2013; Lazard et al., 2010). Phonological skills are often tested in rhyme-judgment tasks, as the ability to adequately represent how words "sound" are diminished with increasing amount of years with impoverished 
hearing. While it might overlap to some degree with working memory, phonological processing is often seen as a separate cognitive process (Alloway, Gathercole, Willis, \& Adams, 2004).

Yet another observation where cognition and hearing seem to be of importance is in dementia research (Davis et al., 2016). When pooling results from 11 studies, Yuan and colleagues (2018) found that there was a doseresponse relationship between hearing function and risk of cognitive impairment, and that the risk of dementia increased by $29 \%$ among the elderly with disabled hearing compared to aged match people with normal hearing. Attending to hearing loss in midlife was recently recognized as the most important modifiable risk factor for this age strata (Livingston et al., 2017). However, caution is recommended when trying to interpret the relationship between hearing loss and cognitive decline (Wayne \& Johnsrude, 2015). The studies have often been correlational, and measures of both cognition and hearing ability have varied greatly.

In this thesis, both working memory capacity and phonological skills were measured (Study I \& Study II).

\section{Hearing and acceptance}

As described earlier, professionals in the field of audiology have for decades observed both that people with hearing loss wait for years before seeking help and also that when they have received hearing aids, they often leave their devices in a file-drawer (Davis et al., 2007; Hartley et al., 2010). Some researchers have classified this phenomenon as signs of lacking acceptance (Knudsen et al., 2010; Light \& Looi, 2011; Wallhagen, 2010). Attempts at measuring this construct has also been made, for example the self-report scale called the Communication Profile for the Hearing Impaired [CPHI] has subscales devoted to acceptance (Demorest \& Erdman, 1986).

Rarely have attempts been made to define the construct in more detail. Mostly, the term is used interchangeably with toleration. This is the case in several items on the CPHI, where it is something quite passive and a hurdle to get over and then not revisit. In other items, it is more akin to a personality trait. In addition, as acceptance often is described in a trait-like fashion little 
attention is given to how it could change to allow for more adaptive behaviours.

In the last two decades, acceptance has received a renewed interest in the field of clinical psychology. Most of this increase comes from proponents of the so-called 'third-wave' of behavioural therapies, where the first wave is classic behaviour therapy and the second wave being the introduction of cognitive behaviour therapy [CBT] (Hayes, Villatte, Levin, \& Hildebrandt, 2011). There are several different forms of therapies in this so-called third wave with Acceptance and Commitment Therapy [ACT] being the most studied one.

In ACT, acceptance is defined in terms of ongoing overt or covert behaviours. It entails being active and aware of thoughts and feelings without futile attempts to alter them (Hayes, Luoma, Bond, Masuda, \& Lillis, 2006). As an example, interventions in ACT for chronic pain conditions can include exercises where the patient is guided through recognizing the sensations from the area of the body that is painful without distraction or trying to alter the feeling (Dahl \& Lundgren, 2006; Wicksell, Ahlqvist, Bring, Melin, \& Olsson, 2008). This does of course not mean that an acceptance-based approach mean that people should not try to solve problems or alter things or sensations that are bothering them in some way. The focus is instead on not trying to change that which is beyond one's control and not waste time or energy away from what people value in their life (Hayes, Strosahl, \& Wilson, 1999).

It is important to note that the definition of acceptance within third-wave therapies is not one where increased acceptance is a goal in itself. Instead, it is conceptualized as a mean to be able to perform meaningful behaviours in line with one's values (Hayes, Luoma, Bond, Masuda, \& Lillis, 2006). It is thus neither a moderator (Baron \& Kenny, 1986) or an outcome in its own right but rather is proposed to function as a mediator. That is, a construct that is important in the relation between the intervention and the outcome (Kazdin, 2007).

Values play a key role in ACT, where the goal usually is to increase behaviours that are in line with what one values, and treatment can involve approaching these values and even while having negatively-laden private 
events at the same time (McCracken, Carson, Eccleston, \& Keefe, 2004). Beyond a rationale of diverting one's time and energy to things that matter, rather than a Sisyphean struggle with private events, it can also be logical from a symptom burden perspective. This is because a decrease of negatively reinforced avoidance behaviours is important as these behaviours might in the end only increase symptoms even though they might offer short term relief, as is the case in many classical CBT rationales for psychiatric disorders (see for example O'Donohue \& Fisher, 2008). As exemplified above, classical CBT is not necessarily incompatible with ACT-principles and proponents of ACT sometimes describe ACT as a variant of CBT rather than something completely different (Hayes et al., 2011).

Is ACT then actually better than CBT? When compared against each other in psychological treatment of anxiety disorders, the results at follow-up are largely comparable (Arch et al., 2012). The same pattern, with very similar results at follow up was observed in a treatment for tinnitus (Hesser et al., 2012). It might be possible that the process of change is different, but not the end results, although there is yet not enough empirical evidence to support this notion.

This perspective on what acceptance is has not been previously received much attention in relation to people with hearing loss. One exception is a published study protocol, in which acceptance as applied to hearing problems was described as an inclination to avoid emotions and cognitions related to the impairment (Weineland et al., 2015). Acceptance in this case also entails disengagement of struggling with the experience of hearing loss in a maladaptive way (such as for example avoiding social activities), and an engagement in positive and meaningful everyday activities. In an interview study, Wänström and colleagues (2014) applied basic ACT concepts to understand how people who recently had a hearing aid fitted reasoned about their process from avoidance to acceptance. This article showed that the relevant theoretical concepts in ACT could be applied to hearing loss, and that the ACT-model overall seemed to be feasible. This qualitative study identified several themes that are congruent with ACT theory, such as the detrimental effects of experiential avoidance. 


\section{Hearing and experiential avoidance}

The description of acceptance in relation to hearing loss offered by Weineland et al. above has a face validity for the problems that are common among people who avoid to seek hearing rehabilitation. The description of the link between acceptance and hearing problems has several similarities with the term experiential avoidance. Experiential avoidance is commonly defined as the very opposite of acceptance (Vilardaga, Hayes, \& Levin, 2009). It was originally described as unhealthy efforts of avoiding/escaping from private sensations (memories, emotions, thoughts, and other experiences unique to the individual) (Hayes, Wilson, Gifford, Follette, \& Strosahl, 1996).

In classical coping theory, there are strategies centred on avoidance and dealing with the emotional impact of life events. These terms share some overlap with experiential avoidance, both in practice as well as in theory (Karekla \& Panayiotou, 2011). They are however not identical constructs, but both seem to entail the avoidant coping theory terms denial, disengagement and self-blame. Previously, the use of coping theory in audiology has received criticism for lacking in specificity of definitions, being of unknown use in real-world outcomes, and lacking in flexibility as certain behaviours might be adaptive in some situations but not in others (Andersson \& Willebrand, 2003).

In the case of hearing loss, experiential avoidance could be seen as not seeking help as way of dealing with the problems of negatively loaded personal events - recognizing that hearing is not well (Davis et al., 2007; Southall et al., 2010), or not using hearing aids for fear of being seen as older, incompetent and so forth (Wallhagen, 2010).

A more in-depth description of the kind of experiential avoidance in the case of non-adaptive coping in the face of hearing loss, although not within an ACT-framework, was offered by Williams et al (2015). They studied hearingimpaired people who participated in a stress-management course, and measured hearing performance, psychological distress, use of conversation tactics, as well as fear of negative evaluation by others. They found that both being avoidant in use of communication strategies as well as fearing negative evaluations by others contributed to overall depression, but neither objective nor subjective hearing performance affected depressive symptoms. 
Similarly, the same trend was observed in a longitudinal study of people with sensory loss (hearing or vision) (Lehane, Dammeyer, \& Wittich, 2017). They found that avoidant or distraction-based coping strategies was deleterious to psychological well-being, while those with an active and more accepting coping style fared better. Further, they also found that the spouses of those affected by sensory loss tended to adapt the same kind of strategies as the person with hearing or vision loss.

In this thesis, psychological acceptance was measured with a new questionnaire in the data collection of Study II, resulting in a psychometric evaluation in Study III. Further, psychological acceptance was a key concept in the treatment presented in Study IV. 


\section{Hearing rehabilitation}

Globally, most persons with hearing loss are not treated (Wilson, Tucci, Merson, \& O'Donoghue, 2017). The recommended intervention for most cases are hearing aids for those with mild-to-severe hearing loss and cochlear implants for those with severe-to-complete hearing loss. As hearing aids have become better and more convenient to use, patient satisfaction has risen (Kochkin, 2010). Teaching hearing strategies and sign language are recommended alternatives for cases when use of technical devices have not been successful or not possible (for example when cochlear implants are unsuitable).

Early treatment for age-related hearing loss is recommended as this can mitigate some negative consequences (Wilson et al., 2017). For example, hearing aid use has a positive impact on working memory performance (Rönnberg et al., 2014). Hearing aid use also seems to increase quality of life [QoL], especially on measures of hearing-related QoL (Ciorba, Bianchini, Pelucchi, \& Pastore, 2012). In addition, hearing aid use is associated with lower ratings of loneliness (Pronk et al., 2011). It is to date unclear if hearing aid use is feasible for dementia prevention (Livingston et al., 2017). An alternative to fitting hearing aids is the option of using hearing assistance technology. This technology, sometimes referred to as assistive listening devices, can be used in several situations. Typically they contain a transmitter at the sound source (such as announcement speakers at a train station, the microphone in an auditorium, or a television set) and a receiver (such as cordless headphones) (Laplante-Lévesque, Hickson, \& Worrall, 2010).

A third option, beyond hearing aids and hearing assistance technology, is participation in some form of communication program (Laplante-Lévesque et al., 2010). These can be group-based or tailored to the individual. Usually they aim to improve speech perception or communication skills through auditory training, speechreading, and hearing strategies. Some, like the Active Communication Education [ACE] program, can be used both by those with hearing aids as well as those without, and has shown to be effective (Hickson, Worrall, \& Scarinci, 2007). Authors often argue for the need of using several of these kinds of approaches but in real-life, this is rarely the case. 


\section{Psychological and behavioural interventions in audiology}

Beyond hearing aids, other treatment options for people with hearing loss mostly are of an educational character. Sometimes, they are seen as alternatives to technical interventions where devices play a crucial role, and other times they are seen as adjuncts to treatment to improve usage and benefit from hearing aids (Hickson et al., 2007; Sundewall Thorén, Öberg, Wänström, Andersson, \& Lunner, 2014). This is achieved by, for example, teaching hearing and communication strategies, how to handle a hearing aid, and lip-reading skills. A recent review of audiological rehabilitation programs for facilitating hearing aid use concluded that educational programs seemed to be more effective than counselling ones, and that they are most successful when it comes to using communication strategies and less so for hearing aid usage and perceived hearing disability (Aazh \& Moore, 2017).

As reported earlier, cognitive processes are of importance for hearing. In the last decade different computerized working memory training program have been developed. These programs aim at increasing general working memory performance as a means of helping people with cognitive dysfunction (Klingberg, 2010). However, the positive early results indicated that there rarely is any transfer of gains to more general functions (Shipstead, Redick, \& Engle, 2012). If working memory capability is a key to understanding speech in noisy environments, it may be the case that training on working memory tasks can be a helpful intervention. However, one study found no effect of working memory training on hearing ability in noise (Wayne, Hamilton, Huyck, \& Johnsrude, 2016). Another randomized controlled trial $[\mathrm{RCT}]$ found no generalized benefit to real-world situation, but that training on more specific parts of auditory perception might be a helpful further line of research (Ferguson \& Henshaw, 2015). One interesting later study indicated that letting elderly people with hearing loss play a game on an tablet where the task is to monitor subtle changes in predicted and actual auditory feedback might increase word identification in spoken sentences in background noise (Whitton et al., 2017). However, gains were lost when training stopped and it had little effect on real-life performance. 
Another treatment approach for hearing loss is through a behavioural perspective, more akin to the way that psychological therapies are structured. One such example of face-to-face therapy, where principles of behaviour therapy was applied to hearing loss, was conducted in the mid-nineties in the form of a RCT (Andersson, Melin, Scott, \& Lindberg, 1994). This small study based interventions and treatment goals on individualized functional analysis. It also featured other aspects commonly found in behavioural treatments such as homework assignments between sessions, exposure with response prevention and behavioural experiments in addition to the overall treatment content featuring hearing tactics and coping skills. This kind of behavioural approach, although with more of a focus on applied relaxation and behaviour change in challenging listening situation, was also successful in a group format RCT which also included behavioural outcomes in a structured interview (Andersson, Melin, Scott, \& Lindberg, 1995).

There are other examples of when treatment types that originates from a behavioural, or cognitive-behavioural, tradition are applied to people with audiological problems. One such example is a self-help program for people with acquired deafness who also suffered from depression or anxiety (Garnefski \& Kraaij, 2012). This intervention was delivered as a book for self-studies, a workbook and an accompanying CD-ROM. The content was derived from more general self-help programs for people with physical impairments and mainly focused on relaxation, adjusting maladaptive cognitions, and finally attainment of goals in one's personal life. The authors concluded that the treatment was effective for reducing symptoms of anxiety and depression.

When critically assessing these studies for their methodological soundness, there are several issues. For starters, they do not appear to follow any general outline of how RCT's should be reported and evaluated through the use of checklists, such as CONSORT (Armijo Olivo et al., 2007). Their sample sizes are small, where the studies by Andersson have 9-12 participants per arm (Andersson, Green, \& Melin, 1997; Andersson et al., 1994, 1995). Although the study by Garnefski \& Kraaij had a larger sample size, their choice of method for statistical analysis for the main outcome measure only affords using data for complete cases (RM-ANCOVA), which is especially troubling 
as the intervention arm lost almost a third of its participants to post-test. Further, they interpreted the results that does not meet criteria for statistical significance as though they were significant.

In studies of psychological suffering in the face of another audiological condition, tinnitus, more modern and rigorous studies can be found. For example, Zetterqvist Westin et al. (2011) compared ACT, with Tinnitus Retraining Therapy and a wait-list control condition. By developing a treatment manual for tinnitus using core ACT principles this trial showed that the intervention was effective in reducing tinnitus distress. There are also other CBT or ACT trials for tinnitus which have proven the soundness of a more psychological approach to tinnitus (Hesser, Weise, Westin, \& Andersson, 2011), where group CBT vs internet-CBT (Kaldo et al., 2008), internet-CBT vs wait-list control (Andersson, Strömgren, Ström, \& Lyttkens, $2002 \mathrm{~b}$ ) and internet-CBT vs internet-ACT for example have been tested (Hesser et al., 2012). Hyperacusis, the oversensitivity to everyday sounds, has also been treated with CBT (Jüris et al., 2014).

To summarize, there are several adaptations of CBT or ACT for audiological conditions and these treatments seem to be working well. There are fewer studies of psychological treatment for hearing loss, or rather distress caused by hearing loss. These studies all have several methodological concerns, partly caused by old standards for running trials that makes it hard to judge if they really are working.

\section{Internet delivered treatments}

Using internet delivered psychological treatments in not something new, as this approach now is more than 20 years old (Andersson, 2018). Commonly, this means guided self-help where patients read a section of text, answers questions, conduct homework assignments, and then gets feedback in a text message from the therapist. Other alternatives are programs that are not therapist-guided, those based on chat instead of asynchronous communication, programs with video chat and so on. The internet modality format allows treatment that does not require travel, is cost- and time efficient, acceptable to patients and often comparably effective as face-to-face treatments (Carlbring, Andersson, Cuijpers, Riper, \& Hedman-Lagerlöf, 
2018). It can also serve to reduce barriers for treatment. Further, the relative ease of developing and trialling a treatment as an internet-based treatment in contrast to the cumbersomeness of a face-to-face randomized controlled trial affords a faster pace of delivering new treatments or answering other research questions (Titov, Dear, \& Rapee, 2013). Most interventions are based on CBT, but there are also several studies of ACT. There are also treatments from the psychodynamic tradition (Andersson, 2018; Johansson, Hesser, Ljótsson, Frederick, \& Andersson, 2012), as well as treatments that use physical activity to target depression (Ström et al., 2013)

It is not only shorter times between ideas to completed trial that is an advantage with internet-delivered treatments. The treatment format also facilitates an increased adherence to treatment manuals (avoiding so-called therapist-drift (Waller, 2009) and closer monitoring of treatment progress through frequent measurement of changes in symptoms. Results from treatments are positive for mood disorders and anxiety disorders (Andersson, 2016). There are trials for other conditions as well, such as chronic pain, insomnia, obesity, headache, irritable bowel syndrome, and diabetes, although these have been implemented to a lesser extent than psychiatric disorders.

Even though internet-delivered treatments have been around for a long time, studied for many conditions, and often in more than one trial, several weaknesses or general critiques could also be highlighted. For example, internet-delivered treatments are made to be alternatives or adjuncts to ordinary treatment and are as a rule not to been seen as replacements for other forms of healthcare (Andersson \& Titov, 2014). Some authors have noted that most of the studies are conducted as scientific projects and that there needs to be more evidence of internet-delivered psychological treatments on real world patients (King \& Bickman, 2017), although there are several publications on this kind of patients (Andersson \& Hedman, 2013). Further, although there are several studies of predictors, moderators and mediators in internet-delivered treatments it is still not clear who benefits from treatment (Andersson \& Titov, 2014). In addition, many treatments have been delivered without a proper face-to-face diagnostic procedure. This makes it questionable if a correct diagnosis is determined upon in all cases. Finally, 
some people deteriorate in their condition after being part of an internetdelivered treatment. Although this aspect is understudied to date, rates of deterioration at least seem to be no worse than that of face-to-face treatments (Rozental, Magnusson, Boettcher, Andersson, \& Carlbring, 2017).

\section{The internet and audiology}

Beyond the previously mentioned psychological internet-based treatments for tinnitus (Andersson, Strömgren, Ström, \& Lyttkens, 2002a; Beukes, Baguley, Allen, Manchaiah, \& Andersson, 2017; Hesser et al., 2012; Kaldo et al., 2008), there are also examples of internet-based treatments for persons with hearing loss. Thorén et al. (2011) successfully adapted a group-based treatment for people with hearing loss to work on the internet as a five-week long treatment with one module per week. A further improvement of this program was later achieved by including problem-solving skills, applied relaxation and psychoeducation on how hearing loss affects cognition (Sundewall Thorén et al., 2014). This reworked intervention improved on the previous one and rendered less participation restriction and activity limitation as well as increased psychosocial wellbeing for the intervention group. The results were largely maintained at follow-up. Using the internet for the delivery of health care is especially relevant for hearing-related issues as older adults with slight hearing impairment are more skilled computer-users than their non-impaired counterparts (Henshaw, Clark, Kang, \& Ferguson, 2012).

Efforts have also been made to move some or all of the elements of hearing rehabilitation to the internet using a more blended approach (Malmberg, Lunner, Kähäri, \& Andersson, 2017). There are also studies on how to develop a platforms to facilitate communication between the patient and the audiologist between sessions, follow rehabilitation goals and deliver information (Brännström et al., 2015). Some researchers have developed educational videos for those receiving their first hearing aid with content meant to ease self-management of hearing loss and their hearing aids as well as improve communication skills (Ferguson, Brandreth, Brassington, Leighton, \& Wharrad, 2016). These videos were delivered on DVD, for offline viewing on a PC, or through the internet. They did however not affect hearing aid usage, which was the primary outcome measure, but did improve 
on secondary measures such as practical hearing aid skills, and knowledge about related psychosocial issues.

Another take on using the internet as a vehicle in hearing rehabilitation is offered by researchers interested in increasing motivation for undertaking hearing rehabilitation. Audiologists are increasingly endorsing a motivational interviewing approach, originally developed in the first half of the 1980's for addictive behaviours, to help in the hearing rehabilitation process (Clark, Maatman, \& Gailey, 2012; Prochaska \& Di Clemente, 1982). The underlying stages of change model posits that people go through different stages when undertaking behaviour change (although a change is not thought of as necessarily linear, and people can revert to previous stages), and the model has been adapted for use in audiology (McFarlane, 2012). To determine what stage a client is in, a questionnaire called the University of Rhode Island Change Assessment [URICA] can be used (DiClemente \& Hughes, 1990; Laplante-Lévesque, Brännström, Ingo, Andersson, \& Lunner, 2015). However, recent research indicates that at least among people screening for hearing loss online, similar classification into stages can be done with just a single item (Ingo, Brännström, Andersson, Lunner, \& Laplante-Lévesque, 2017). 


\section{Thesis in context}

To summarize, many people with hearing loss do not seek help or try to get a proper diagnosis. Further, among those with an established hearing loss a significant proportion suffer from psychological distress and feel restricted in their ability live their lives as they wish. One way of understanding these issues is through applying an acceptance-based approach to hearing loss, where the theoretical underpinnings of contextual behavioural science can be used to further the understanding of these issues. Such an approach can both be informed by radical behaviourism and applied functional analysis, and also use newer concepts such as a psychological flexibility (Hayes, Levin, PlumbVilardaga, Villatte, \& Pistorello, 2011).

One caveat that the behavioural tradition for a long time has been warning about when classifying behaviours or psychological conditions is that of focusing too much on topography and too little on function (see for example Skinner, 1974). In audiology, as in the rest of most health care, a more traditional view of classification of patients into set categories has been worked well in many cases. This entails using medical diagnosis as a way for understanding the individual's ill health, guide treatment, and follow-up. Diagnosis is usually done through examining a patient with an eye towards set criteria from a diagnostic manual, such as the International Statistical Classification of Diseases and Related Health Problems published by the World Health Organization (WHO, 2004).

Such classifications of disease, or nosology, have been very helpful in understanding prevalence, usefulness of treatments and common comorbidities (O'Malley et al., 2005). In audiology for example, this form of classification allows for recommending the correct intervention for an individual based on their hearing ability, for example from no intervention, to one or two hearing aids, or cochlear implants, based on severity of the hearing loss (Wilson et al., 2017). But generally speaking, traditional diagnoses cannot describe every condition for every person, or be relied upon to describe all relevant aspect of how an individual is affected (Hayes et al., 1996).

Another way of describing functioning is within the framework of the International Classification of Functioning, also published by the World 
Health Organization (WHO, 2001). This framework is gaining more and more recognition, especially within disability research regarding the participation dimension (Imms et al., 2016). The ICF not only concerns participation, but also the individual's functions and structure and what activities they perform. In a hearing perspective, hearing loss is a body function, listening becomes an activity, and partaking in communication is an example of participation (Heinrich et al., 2015).

This way of describing more in-depth situations where one is not able to function to satisfaction is in some regards similar to functional analysis in the CBT tradition. Both approaches incorporates the unique context of the problematic situation, and does not remain on the more general diagnostic level. This focus is also continued in the ACT treatment approach, which is meant to be a trans-diagnostic treatment (Hayes et al., 2011). Further, as ACT uses workability as a truth criterion (Hayes et al., 2006), objectively true or not diagnoses are of little interest and only to the extent that they are helpful tools to achieve a desired outcome. This view of science is best described as part of a pragmatic tradition (Barnes-Holmes, 2000). The stance is aontological in the sense that the goal of endeavours in this tradition is not interested in what is real, and silent on the issue of ontology, but rather on what is working to get closer to a pre-defined goal (Barnes-Holmes, 2005).

Although not driven strictly by any meta-theoretical perspective, there are elements of a kind of pragmatism in all the four papers. For example, in both internet-based hearing screenings (Study $1 \&$ Study II) hearing loss levels are set at levels where usefulness of an intervention is plausible and not corresponding strictly to diagnostic criteria. The other two papers are more influenced by the theoretical assumptions of acceptance-based psychological interventions.

This thesis is concerned with three different aspects of helping people move from detection of hearing issues to completed rehabilitation. The need for this kind of research is evidenced by the fact that people with hearing loss still are hesitant to seek help, and those that do are in most cases not treated for comorbid psychological issues, which is something that is not helped by fitting a hearing aid (Keidser, Seeto, Rudner, Hygge, Rönnberg, et al., 2015). 
This is done by firstly studying internet-based hearing screening procedures, secondly how to measure hearing loss acceptance, and thirdly treating psychological distress among those with hearing loss using an acceptancebased approach. 


\section{Overall aim}

The overall aim of the thesis was to study the potential of internet-based detection of hearing loss, and treating distress caused by it, with a focus on psychological facets of hearing. The different studies of the thesis can be summarized in three overall research questions. First, can hearing loss be detected through automated online screening procedures, and what are the characteristics of those who participate (Study 1 and 2)? Second, can acceptance be accurately measured in this population using a new questionnaire (Study 3)? Third, and finally, can online-administered self-help based on Acceptance and Commitment Therapy help those with hearing loss and psychological distress (Study 4)?

\section{Study 1}

The aim of the study was to explore the associations between hearing screening, phonological representation, and quality of life as well as selfreported hearing difficulties after validating a new internet-based hearing test. Those who failed the hearing test were then compared on the core outcome measures against those who passed the test.

\section{Study 2}

The second screening study expanded on the first one with a larger sample sizes, refined hearing test and inclusion of both measures of anxiety, depression, as well as more refined cognitive testing.

\section{Study 3}

This study concerns the development and evaluation of a new measure of hearing loss related acceptance. The paper evaluates its core psychometric properties and compares different factor solutions using confirmatory factor analysis.

\section{Study 4}

The final study took the form of a randomized controlled trial. In it, the effects of ACT as an Internet-delivered intervention for people with hearing loss and associated psychological distress was evaluated against a wait-list control group. The main outcome was a measure of hearing related disability, and 
secondary outcomes measures were about depression, anxiety and quality of life. 


\section{Empirical studies}

Study I. Molander, P., Nordqvist, P., Öberg, M., Lunner, T., Lyxell, B., \& Andersson, G. (2013). Internet-based hearing screening using speech-in-noise: validation and comparisons of self-reported hearing problems, quality of life and phonological representation. BMJ Open, 3[9], e003223.

\section{Aim}

This study had two overarching aims. The first one was to evaluate the usefulness of an internet-based hearing test. This test was a speech-in-noise test, where the participant is tasked to identify spoken words in varying background noise. The second goal was to incorporate other measures into the online hearing screening process, and by doing so test if those who failed the test also had a lower quality of life, less cognitive ability and more self-reported issues with their hearing.

\section{Methods}

The first part of the study, the validation of the hearing test, was conducted by recruiting an opportunity sample at Stockholm central train station. The test was taken by 233 participants (female, $n=112$, mean age 61 years, $S D=14$ years, male, $\mathrm{n}=111$, mean age 60.3 years, $\mathrm{SD}=14.5$ years). Ordinary headphones (Sennheiser HD 428, connected to a laptop) was used. A standard audiometric screening of pure tone detection at $250,500,1 \mathrm{k}, 2 \mathrm{k}, 3 \mathrm{k}, 4 \mathrm{k}$ and $6 \mathrm{k}$ frequencies using TDH 39 headphones was also conducted, with the screening level set to $20 \mathrm{~dB}$ HL inside an audiometric sound booth. An ROC curve was then calculated to find the optimal cut-off value for the internetbased hearing test. This cut-off was set to detect at least a $35 \mathrm{~dB} \mathrm{HL}$ as defined by the results of the pure tone detection.

The second part of the study entailed deploying the hearing test online, together with other measures of potential relevance for the hearing loss population. Recruitment was done by advertisement in the national press, and led to 316 participants who signed up for, and in some form started the screening process and gave informed consent. 
Earphones were recommended for the hearing test, but the use of loudspeakers was allowed. After the hearing test, the participants took a series of different tests and self-report measures. There were questions on demographics (age, sex, educational level, living arrangements, a question if they suffered from any serious or chronic disease), and finally questions regarding the use of hearing aids, if they suffered from tinnitus and/or hyperacusis.

Beyond these questions, there was also a rhyming test. This was included as previous research has shown that people with hearing loss have diminished phonological representation skills (Andersson, 2002). Participants were asked to judge if pairs of words rhymed or not within a two-second window of visual word presentation. There were 20 such pairs.

To measure self-rated hearing problems, the Amsterdam Inventory for Auditory Disability and Handicap was included. This measure consists of 30 different questions about different kinds of listening situations. The inventory is then scored on five different subdomains. A translation to Swedish has been performed, with satisfactory psychometric properties (Hallberg, Hallberg, \& Kramer, 2008).

Further, a quality of life inventory, QOLI, was included to test if those affected by a hearing problem would have lower scores on this domain than those unaffected. This measure consists of 16 different life domains that the participant is tasked with rating for both importance (0-2) and satisfaction (from -3 to +3 ) (Frisch, Cornell, Villanueva, \& Retzlaff, 1992). This measure has been evaluated in its Swedish version (Lindner, Andersson, Öst, \& Carlbring, 2013) and has also been validated for online use (Carlbring et al., 2007).

\section{Results and discussion}

Findings from the hearing test showed that $16.7 \%$ of those who participated in the online screening procedure scored above the cut off at $-3.4 \mathrm{~dB}$ and thus was classified as potentially hearing impaired. To no surprise, the older age strata had more difficulties with the hearing test. When comparing those who failed the hearing test to those who passed with a series of independent sample 
$t$-tests, several significant differences emerged. On all the five subscales of the AIADH, those who passed the hearing test reported less perceived handicap. Further, those who passed were significantly better at judging if pairs of words rhymed. However, there were no group difference on the quality of life measure.

Table 1. Difference between groups on the main outcome measures

\begin{tabular}{lcllllll}
\hline Variable & $\begin{array}{c}\text { Failed } \\
\text { (N=48) }\end{array}$ & \multicolumn{2}{c}{ Passed $(\mathrm{N}=239)$} & $\mathrm{t}$ & $\mathrm{df}$ & $\mathrm{p}$ \\
& $\mathrm{M}$ & $(\mathrm{SD})$ & $\mathrm{M}$ & $(\mathrm{SD})$ & & & \\
\hline AIADH average score & 1.08 & $(0.48)$ & 0.64 & $(0.38)$ & 7.03 & 285 & $<.001$ \\
AIADH - Distinction & 0.79 & $(0.43)$ & 0.59 & $(0.31)$ & 3.8 & 285 & $<.001$ \\
AIADH - Localization & 0.84 & $(0.65)$ & 0.46 & $(0.53)$ & 4.39 & 285 & $<.001$ \\
AIADH - Noise & 1.64 & $(0.68)$ & 0.93 & $(0.61)$ & 7.23 & 285 & $<.001$ \\
AIADH - Quiet & 0.93 & $(0.5)$ & 0.51 & $(0.38)$ & 6.54 & 285 & $<.001$ \\
AIADH - Detection & 0.77 & $(0.51)$ & 0.33 & $(0.39)$ & 6.65 & 285 & $<.001$ \\
QOLI & 3.25 & $(1.19)$ & 3.13 & $(1.29)$ & 0.56 & 285 & 0.58 \\
Rhyme judgment & 81.25 & $(12.35)$ & 86.83 & $(11.55)$ & 2.84 & 265 & 0.005 \\
\hline N
\end{tabular}

Note. AIADH - Amsterdam Inventory of Auditory Disability and Handicap, reversed scored where higher scores indicate more problems. QOLI - Quality of Life Inventory.

There was also a stand-alone question in the procedure regarding if the participant felt they had impaired hearing. Answering yes to that question was correlated with performance on the hearing test $(r=0.23, p<.001)$. For reference, the correlation between the hearing test and the AIADH was $r=$ $0.46, p<.001$, indicating that for this sample, the use of a questionnaire was a better option than simple asking a participant if they themselves thought they were hearing impaired. This is however not always the case, where some studies have found that single questions perform quite well, and outperform the Hearing Handicap Inventory for the Elderly (HHIE) as a diagnostic tool (Nondahl et al., 1998; Salonen et al., 2011). The discrepancy in results might well be attributed to the fact that the present study used the AIADH, and not the HHIE.

Among the participants, problems with both tinnitus and hyperacusis, were quite common where $39.6 \%$ answered yes to having tinnitus (average population $14.2 \%$ ) (Axelsson \& Ringdahl, 1989). Oversensitivity to 
everyday sound was reported by $24.1 \%$ of the participants, while this complaint only was found among $8.6 \%$ of the average population (Andersson, Lindvall, Hursti, \& Carlbring, 2002).

There was no difference between those who passed and those who failed the hearing test regarding quality of life. This results was unexpected, as several previous studies have found that degraded hearing ability is linked to worse quality of life (Dalton et al., 2003; Hogan, O'Loughlin, Miller, \& Kendig, 2009). One could speculate that this also is a case of QoL is measured, and that the QoLI differs in its makeup quite a bit from more traditional healthrelated quality of life questionnaires used in other studies. It could also possibly be attributed to different kinds of samples. 
Study II. Molander, P., Nordqvist, P., Ellis, R., Rönnberg, J., Lyxell, B., Dahlström, Ö., Lunner, T., \& Andersson, G. (submitted manuscript]. Online administration of a speech-in-noise test and its relationship to hearing problems, cognition and psychological distress.

Aim

The aims of the present study were to both improve the properties of an online hearing test, and to test if psychological distress and cognitive abilities were related to hearing performance. Further, we aimed at exploring how different demographical characteristics of the participants might influence the results.

\section{Methods}

In this two-part study, the first part was dedicated to evaluating an improved version of the same hearing test as used in Study 1 . This was achieved by lowpass filtering the background noise used. Previous research has revealed that by adding low-pass filtering, more information in the higher frequency area of speech is retained (Leensen, de Laat, \& Dreschler, 2011). The new test was evaluated by attendants at a conference who were at least 18 years old and not hearing aid users. A total of 103 participants were recruited (59 of which were women, mean age was 60 years old (SD 17 for women, SD 11 for men). The rest of the testing followed the same procedure as in Study 1.

The second part of the study meant that the new hearing test was incorporated in an online hearing screening procedure together with demographical, hearing-related standalone questions, established questionnaires and test of cognitive ability. Specifically, the Hospital Anxiety and Depression Scale (HADS) was incorporated as a measure of psychological distress, the Amsterdam Inventory of Auditory Disability and Handicap as a measure of self-rated hearing problems, as well as the Quality of Life Inventory. Further, phonological representation skills, which are diminished among those who has been suffering from hearing loss for longer periods of time (Andersson, 2002), were tested with the same rhyming test as in Study 1. Finally, the Trail Making Test was computerized for use in the present study as a test of perceptual speed and working memory. This test consists of two parts, where 
the A part tasks participants to draw a line between numbers in increasing order. Thereafter, in the B part, numbers and letters are both included in the stimulus material and the participant is tasked with altering between symbols in the line drawing, thus making a line between 1 to $\mathrm{A}$ to 2 to $\mathrm{B}$ and so forth. In a separate publication, the optimal way of scoring this version in relation to hearing ability was determined to be the time it takes to complete the B version of the test (Ellis et al., 2016). Recruitment to the online screening was performed using advertisement in the national press.

\section{Results and discussion}

By agreeing to the conditions of the study, an e-mail was sent to the potential participants. A total of 1509 people then actually visited the webpage of the study and began the procedure. Of those, 1370 completed the actual hearing test, and 1006 in addition completed the two cognitive tests and the three questionnaires.

The prevalence of hearing loss in the current sample was $19 \%$. More than half of the participant, $51.5 \%$, answered yes for having tinnitus while $22.2 \%$ said that they suffered from hyperacusis.

As a first step, odds ratios for the included measures was computed for the complete sample, as well as divided into different demographical subgroups. The results revealed that self-rated hearing problems on the AIADH was significantly related to failing the hearing test (OR $4.8895 \%$ CI 3.37, 7.06). Male gender was also associated with failing the hearing test, OR 1.48 (95\% CI 1.21, 1.73). Further, being at least 65 years old was also associated with failing the hearing test (OR 4.44, 95\% CI 3.19, 6.17). Finally, those who did not have a college/university level education also failed the test to a higher degree (OR 2.6 95\% CI 1.96, 3.42).

There were also several instances of results that was associated with passing the hearing test. These were high cognitive ability (TMT-B OR $0.1895 \%$ CI $0.01,0.33$ and for the Rhyming test OR $0.495 \%$ CI $0.24,0,67$ ), and being classified as a definite case for anxiety on the HADS-A (OR 0.39, $95 \%$ CI $0.19,0.82)$. 
When examining all the included measures together in a hierarchical regression model, with the demographical variables included in the first step. The second step included self-rated hearing problems with the AIADH, the third step also added the cognitive measures (TMT-B and the rhyming test), and in the fourth step the HADS and QOLI was added.

Table 2. Hierarchical logistic regression on hearing outcome

\begin{tabular}{|c|c|c|c|}
\hline & Odds ratio & $(95 \% \mathrm{CI})$ & $\begin{array}{l}\text { Nagelkerke } \\
\mathrm{R}^{2}\end{array}$ \\
\hline Step 1 & & & 0.13 \\
\hline Gender & 1.57 & $(1.08-2.28)$ & \\
\hline Age & 3.31 & $(2.23-4.9)$ & \\
\hline Education & 0.47 & $(0.33-0.67)$ & \\
\hline Step 2 & & & 0.18 \\
\hline Gender & 1.55 & $(1.05-2.27)$ & \\
\hline Age & 3.38 & $(2.26-5.05)$ & \\
\hline Education & 0.52 & $(0.36-0.74)$ & \\
\hline AIADH & 4.02 & $(2.46-6.56)$ & \\
\hline Step 3 & & & 0.2 \\
\hline Gender & 1.56 & $(1.06-2.29)$ & \\
\hline Age & 3.34 & $(2.23-5.02)$ & \\
\hline Education & 0.57 & $(0.4-0.82)$ & \\
\hline AIADH & 4.14 & $(2.52-6.8)$ & \\
\hline TMT & 0.25 & $(0.12-0.52)$ & \\
\hline Rhyme & 0.82 & $(0.39-1.73)$ & \\
\hline Step 4 & & & 0.2 \\
\hline Gender & 1.52 & $(1.03-2.23)$ & \\
\hline Age & 3.16 & $(2.1-4.75)$ & \\
\hline Education & 0.57 & $(0.39-0.82)$ & \\
\hline AIADH & 4.3 & $(2.59-7.12)$ & \\
\hline TMT & 0.25 & $(0.12-0.52)$ & \\
\hline Rhyme & 0.85 & $(0.4-1.79)$ & \\
\hline HADS-A & 0.46 & $(0.14-1.48)$ & \\
\hline
\end{tabular}




$\begin{array}{lll}\text { HADS-D } & 0.7 & (0.07-6.64) \\ \text { QOLI } & 0.95 & (0.28-3.26)\end{array}$

When examining the results this way, the association between anxiety and hearing no longer was significant. Further, the rhyming test was no longer significant, probably because of the presence in the model of the better suited TMT-B test.

The pseudo measure of explained variance, Nagelkerke R2, was overall low for all the steps, and the addition of HADS and QOLI as a final step did nothing to improve the model.

As the last step of analysis, we examined if medical background or other demographical properties were related to hearing performance. Overall, no such relationships were found except for the category parenthood. Even after controlling for gender, age, education, cognitive ability, anxiety, depression and quality of life, we found that those who were parents had a higher risk of failing the hearing test (OR 2.3, $95 \%$ CI 1.16, 4.55).

In conclusion, two measures stood out as being related to hearing ability - the AIADH and TMT-B. Previous research has pointed out how important selfrated hearing ability is in relationship to successful rehabilitation, in the sense that those who really rate their hearing as poor, irrespective of objective performance, are those who are more likely to visit an audiologist for assessment and rehabilitation (Knudsen et al., 2010).

The present study found no relationship between depression or anxiety and hearing in the multivariate context. This finding goes against previous research, where anxiety has been linked to hearing (Contrera et al., 2017). It seems probable that differences in recruitment strategy (older adults with hearing aids fitted vs self-recruited general population) might account for some of this difference.

Finally, the amount of people passing the hearing test is interesting. Of course, signing up for the study might be done for several reasons not restricted to worrying about poor hearing ability as pure curiosity might be 
behind participation. It is also plausible that since higher levels of education is linked to more adaptive health-behaviours (Kickbusch, 2001), and the sample in the current study was overall highly educated, that several participants took the test in as part of generally tending to their health in a proactive way without really being that concerned about their own hearing. However, it seems likely that most of those who signed up for the test also thought that they might suffer from hearing loss but only about one in five had hearing issues according to the test. This stresses that measures of both objective and subjective hearing problems are valuable in the screening process in the sense that objective measures might capture those with a real problem, while the subjective measures indicate the probability of successful rehabilitation. 


\section{Study III. Molander, P., Andersson, G., \& Hesser, H. (submitted). Measuring psychological acceptance of hearing loss - Psychometric evaluation and validation of the Hearing Acceptance Questionnaire.}

\section{Aim}

Based on theories and empirical work on psychological acceptance in other areas, primarily in tinnitus and chronic pain, the aims of the current study were to develop and evaluate a theoretically sound questionnaire for measuring psychological acceptance in people with hearing problems. Previous work in this area has been restricted to only changing the wording to "hearing problems" from a questionnaire about tinnitus acceptance.

\section{Methods}

The development of the new questionnaire began with examining existing instruments with similar aims but constructed for use in other populations, such as the Acceptance and Action Diabetes Questionnaire (Gregg, Callaghan, Hayes, \& Glenn-Lawson, 2007), the Chronic Pain Acceptance Questionnaire (McCracken, Vowles, \& Eccleston, 2004) and the Tinnitus Acceptance Questionnaire (Westin, Hayes, \& Andersson, 2008). A set of potential items were then generated, many inspired by the questionnaires, and after discussion between authors a final set of 12 items were settled upon. Answers ranged on a scale from 1 (Never true) to 7 (Always true), with the three first questions being reversed scored.

This Hearing Acceptance Questionnaire (HAQ) was then incorporated in an internet-based hearing screening study, the one reported in Study II. This allowed the HAQ to be completed by participants who were worried about their hearing status.

There were two overall aims of the evaluation of the HAQ. The first one was to perform analysis of the different psychometrical properties of the HAQ by determining inter-item correlation and a suitable factor structure. Given that the HAQ was developed based on previous examined questionnaires and theory, which have been constructed to usually have two factors, 
confirmatory factor analysis (CFA), rather than exploratory factor analysis, was used. By comparing models with different factor structures allowed us to empirically evaluate the assumed two-factor solution by direct comparison in terms of model fit. First, a unidimensional model with a single underlying factor was fitted to the items (model 1). Second, a correlated two-factor model with the 3 items loaded on a first scale presumably measuring Activity Engagement and the following 9 loaded on second scale measuring Avoidance (model 2). The third model was constructed by separating the Avoidance scale into two subscales, one measuring emotional and cognitive avoidance and the other measuring overt avoidance (model 3).

The second aim was to explore the instruments possible unique predictive value of acceptance in relation to hearing disability when controlling for hearing test performance and psychological distress, by using correlation and multiple regression analysis. We expected that HAQ would be uniquely associated with hearing problems in a regression model in which other relevant correlates of hearing problems were included (objective hearing performance, depression, anxiety symptoms).

\section{Results and discussion}

By including the HAQ into the larger battery of tests and questionnaires that was used in the online screening study, 1343 participants completed the questionnaire. There were slightly more men than women (47.6\% women) who participated. They were on average 62.5 years old $(\mathrm{SD}=13.2)$, with the youngest participant being 18 years old and the oldest 93. Education-wise, 57 $\%$ had a university or college level education, $23.4 \%$ had completed a highschool level education and the remainder had only basic level education. 


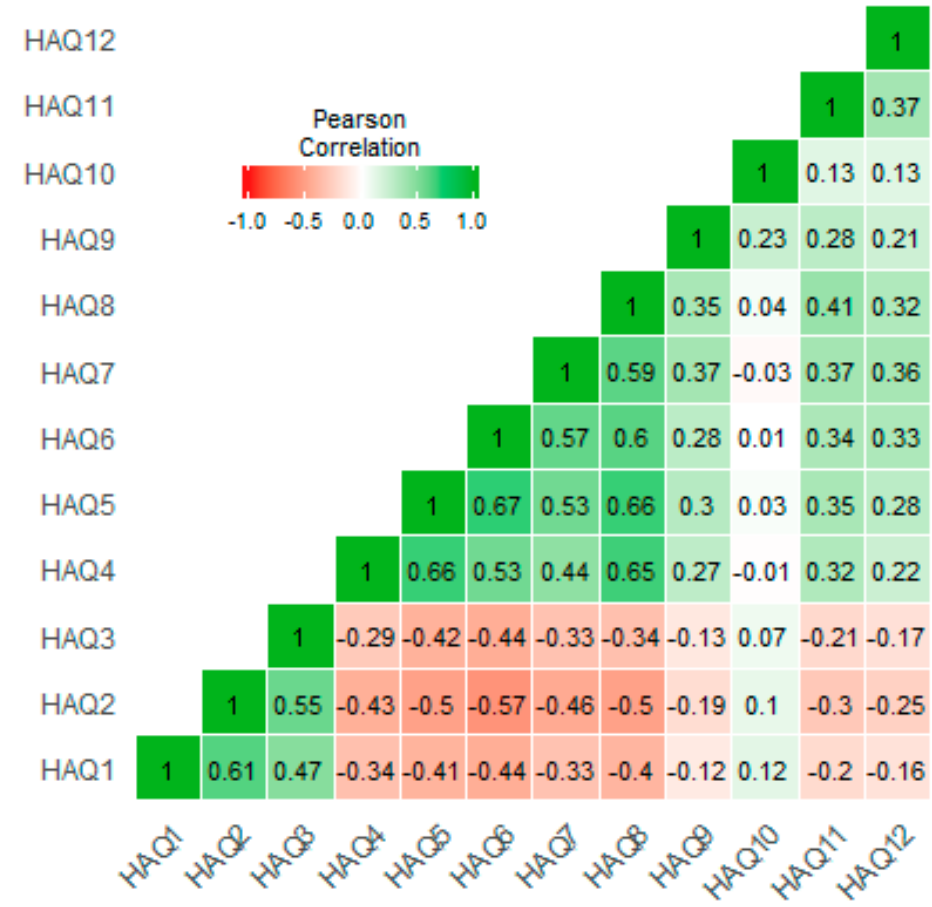

Figure 1.Correlational heat map of all items on the $H A Q$

As a first step, inter item correlations were calculated, as can been seen in Figure 1. Overall, acceptable values were found but item 10 correlated negatively or very weakly with several other items, in all three possible models. Therefore, this item was removed, and the remaining 11 items were included in the following CFAs.

Table 3. Model fit for the three possible factor solutions of the HAQ

\begin{tabular}{ccccccc}
\hline & $\chi^{2}$ & df & $\mathrm{p}$ & CFI & RMSEA & $90 \%$ CI \\
\hline Model 1 & 880.05 & 44 & $<.001$ & 0.87 & 0.12 & $0.11,0.13$ \\
Model 2 & 426.79 & 43 & $<.001$ & 0.94 & 0.08 & $0.07,0.09$ \\
Model 3 & 328.3 & 41 & $<.001$ & 0.95 & 0.07 & $0.07,0.08$
\end{tabular}

Note. CFI - Comparative Fit Index. RMSEA - Root Mean Square Error of Approximation. 
With increasing number of subscales, $\chi^{2}$ values improved. However, the $\chi^{2}$ test performs quite poorly in samples with over 400 participants (Kenny, 2015). It should therefore be interpreted with caution in the current sample. The values in current study remained significant in all models. The same trend, with better values for increasing complexity, was found for the CFI which had acceptable values, >0.9, for Model 2 and good, 0.95, for Model 3 . Finally, the RMSEA also improved with a three-factor solution, and Model 2 and 3 reached an acceptable level at .08 or lower. The upper level of the confidence interval was also within recommendations for Model 3, where it should not be larger than 0.08 (Schreiber et al., 2006).

Internal consistency was also evaluated with Cronbach's alpha in Table 4. Model 1, the unidimensional alternative, had good internal consistency. The other models had lower values, with Model 2 having Cronbach's alpha between .76 and .84 , and Model 3 in one case only having questionable internal consistency, ranging between .64 and .87 .

Table 4. Internal consistency for the possible Hearing Acceptance Questionnaire factors

\begin{tabular}{lccccc}
\hline & Overall & $\begin{array}{c}\text { Activity } \\
\text { Engagement }\end{array}$ & Avoidance & $\begin{array}{c}\text { Overt } \\
\text { Avoidance }\end{array}$ & $\begin{array}{c}\text { Emotional } \\
\text { Avoidance }\end{array}$ \\
\hline Model 1 & .86 & - & - & - & - \\
Model 2 & - & .76 & .84 & - & - \\
Model 3 & - & .76 & - & .87 & .64 \\
\hline
\end{tabular}

Thereafter, factor loadings were examined. Model 1 had acceptable standardized values for most items, but item nine and eleven were just under the recommended cut-off at $<.4$ The same items remained on the lower end for Model 2. Model 3 did not have any such issues.

When examining concurrent validity, seen in Table 5, all correlations were significant. 
Table 5. Correlations between different subscales of the HAQ as well as their correlations with other measures

\begin{tabular}{|c|c|c|c|c|c|c|c|c|c|}
\hline & & & & Scale & & & & & \\
\hline & Model 1 & $2 \mathrm{~F} \mathrm{AE}$ & $2 \mathrm{~F} \mathrm{~A}$ & 3F EA & $3 \mathrm{~F} \mathrm{OA}$ & HAD A & HAD D & $\begin{array}{l}\text { QOL } \\
\text { I }\end{array}$ & $\begin{array}{l}\text { AIAD } \\
\mathrm{H}\end{array}$ \\
\hline Model 1 & 1 & .72 & .97 & .83 & .91 & .27 & .33 & -.3 & .6 \\
\hline $2 \mathrm{~F} \mathrm{AE}$ & & 1 & .55 & .38 & .58 & .2 & .28 & -.34 & .52 \\
\hline $2 \mathrm{~F} \mathrm{~A}$ & & & 1 & .88 & .9 & .26 & .31 & -.25 & .55 \\
\hline 3F EA & & & & 1 & .59 & .26 & .24 & -.18 & .44 \\
\hline 3F OA & & & & & 1 & .22 & .31 & -.26 & .54 \\
\hline HAD-A & & & & & & 1 & .6 & -.47 & .15 \\
\hline HAD-D & & & & & & & 1 & -.61 & .22 \\
\hline QOLI & & & & & & & & 1 & -.11 \\
\hline AIADH & & & & & & & & & 1 \\
\hline
\end{tabular}

Note. $2 \mathrm{~F}$ AE = Two Factor Activity Engagement. $2 \mathrm{~F} \mathrm{~A}=$ Two Factor Avoidance. $3 \mathrm{~F}$ EA = Three Factor Emotional Avoidance. $3 \mathrm{~F} \mathrm{OA}=$ Three Factor Overt Avoidance. EA = Emotional Avoidance. HAD A = anxiety subscale of the Hospital Anxiety and Depression Scale. HAD D = depression subscale of the Hospital Anxiety and Depression Scale. QOLI = Quality of Life Inventory. HAD A = anxiety subscale of the Hospital Anxiety and Depression Scale. AIADH $=$ Amsterdam Inventory of Auditory Disability and Handicap. All corelations significant, $p<.01$.

All models of the HAQ subscales correlated between $r=.2$ and $r=.33$ with the measures of anxiety and depression, between $r=.18$ and $r=.34$ on the QoLI, and with the measure of hearing disability (AIADH) between $r=.44$ and $r=.6$.

As both anxiety and depression, as well as the different possible variants of the HAQ, correlated with hearing disability, the relative importance of these measures warranted further investigation. To address this, hierarchical multiple regressions were performed, with hearing disability as measured by the AIADH as the dependent variable and with hearing test performance (step 1), anxiety, depression, and QoL (step 2), and the different variants of the HAQ (step 3), as independent variables.

Table 6. Hierarchical regression on hearing disability

\begin{tabular}{lccc}
\hline & $B(95 \% \mathrm{CI})$ & $\beta$ & $\mathrm{R}^{2}$ \\
\hline Step 1 & $0.15(0.12-0.17)$ & $.32^{* *}$ & 0.1 \\
Hearing SNR & & & 0.17 \\
Step 2 & $0.15(0.13-0.18)$ & $.33^{* *}$ & \\
Hearing SNR & $0.04(0.00-0.08)$ & $.06^{n s}$ & \\
HAD A &
\end{tabular}




\begin{tabular}{lccc} 
HAD D & $0.09(0.03-0.15)$ & $.18^{*}$ & \\
QoLI & $-0-22(-0.33-0.1)$ & $-0.13^{* *}$ & \\
Step 3A - Two Factor & & & 0.41 \\
Hearing SNR & $0.1(0.08-0.12)$ & $.22^{* *}$ & \\
HAD A & $0.00(-0.03-0.04)$ & $0.0^{n s}$ & \\
HAD D & $0.02(-0.03-0.08)$ & $.03^{n s}$ & \\
QoLI & $-0.03(-0.13-0.07)$ & $-.02^{n s}$ & \\
HAQ Activity Engagement & $0.21(0.17-0.25)$ & $.27^{* *}$ & \\
HAQ Avoidance & $0.09(0.08-0.1)$ & $.35^{* *}$ & \\
Step 3B - Three Factor & & & 0.41 \\
Hearing SNR & $0.1(0.08-0.12)$ & $.22^{* *}$ & \\
HAD A & $0.00(-0.03-0.04)$ & $.01^{n s}$ & \\
HAD D & $0.03(-0.02-0.08)$ & $.03^{n s}$ & \\
QoLI & $-0.03(-0.13-0.07)$ & $-.02^{n s}$ & \\
HAQ Activity Engagement & $0.2(0.6-0.25)$ & $.26^{* *}$ & \\
HAQ Overt Avoidance & $0.1(0.08-0.13)$ & $.24^{* *}$ & \\
HAQ Emotional Avoidance & $0.08(0.05-0.1)$ & $.16^{* *}$ & \\
\hline
\end{tabular}

Note: SNR: Signal to Noise Ratio. HAD A = anxiety subscale of the Hospital Anxiety and Depression Scale. HAD D = depression subscale of the Hospital Anxiety and Depression Scale. QoLI $=$ Quality of Life Inventory. $\mathrm{SnR}=$ Signal to Noise Ratio. $* p<.05 . * * p<.001$. $n s=$ Not Significant.

The results showed that the HAQ was a stronger predictor of hearing disability than the hearing in noise test. For Model 2, this was the case for both possible subscales independently. For Model 3B, where avoidance was divided into two separate subscales, the one measuring overt avoidance was also independently a stronger predictor, as was the activity engagement subscale.

The main goal of the current study was to evaluate different factor solutions of the HAQ using CFA. The three models had some unique advantages. Going by the fit indices of the CFA's, a slight favoured solution was Model 3. However, such a solution also led to one of the subscales (Emotional Avoidance) having only questionable internal consistency. Therefore, we recommend that further usage of the HAQ is based on a two-factor solution, 
Activity Engagement and Avoidance, as this variant comes very close to the CFA properties of Model 3.

Another noteworthy result is that from the regression models, showing that hearing acceptance contributed more to the explained variance of hearing disability than actual hearing ability as measured by the speech-in-noise test. While this might seem surprising at a first glance, similar results have been found for other conditions indicating the pivotal role of acceptance in retaining quality of life in the face of disability. For example, the kind of pattern has been observed in chronic pain patients (McCracken, 1998). Acceptance was also of more importance in the model than depression and anxiety. It also highlights the complexity of how humans perceive hearing loss. 
Study IV. Molander, P., Hesser, H., Weineland, S., Bergwall, K., Buck, S., Jäder Malmlöf, J., Lantz, H., Lunner, T., \& Andersson, G. [2018). Internet-based acceptance and commitment therapy for psychological distress experienced by people with hearing problems: a pilot randomized controlled trial. Cognitive Behaviour Therapy, 47, 169-184.

\section{Aim}

This study aimed at delivering guided internet-based psychological treatment for people suffering from hearing loss and comorbid psychological distress. The treatment was based on Acceptance and Commitment Therapy principles and was eight weeks long. The design was a randomized controlled trial with a wait-list control group. The main hypothesis was that the treatment group would improve more than the control group on the main measure of psychosocial handicap, but also on secondary measures of depression, anxiety and quality of life.

\section{Methods}

Participants were recruited through advertisement in newspapers, by information published on the Swedish Hard of Hearing associations Facebook page, and through information in the membership magazine of the Swedish National Pensioners' Organization. By assessing potential participants through a screening procedure online, where only those with at least eight scores on the measure of distress, the Hearing Handicap Inventory for the Elderly - Screening version (HHIE-S), 109 potential participants showed interest for the study. These were then further contacted for a telephone interview to assess suitability for the study and to undergo a MINI v6 psychiatric interview (Sheehan et al., 1998). Out of those, 61 met inclusion criteria of suffering from scoring above 8 on the HHIE-S, were Swedish citizens, having hearing difficulties and showing relevant signs of psychological distress (depressive symptoms, increased anxiety or avoidance behaviours, or lowered quality of life). None of these participants met the exclusion criteria of having a severe psychiatric condition or negating distress related to hearing loss. 
The participants were then randomized to either condition, 30 to WLC and 31 to the intervention. There were no differences between groups on gender, age, marital status, education, employment status or previous mental health treatment experience, all $p>.36$.

The intervention was conducted through the internet, with all treatment material available online separated into eight different modules. The material consisted of text, images and sound files. The total amount of text corresponded to 133 pages of print on A4-pages. After each module was completed, with the themes visible in Table 7, the therapist provided written feedback on the exercises and any other questions that the participant might have had.

Table 7. Treatment content.

\begin{tabular}{|c|c|c|}
\hline Title & Content & Homework \\
\hline 1. Introduction & $\begin{array}{l}\text { Facts about hearing, } \\
\text { suffering, values }\end{array}$ & $\begin{array}{l}\text { Clean and dirty suffering, } \\
\text { mindfulness }\end{array}$ \\
\hline 2. Direction of your life & Values, hearing difficulties & $\begin{array}{l}\text { Defining values, avoidance } \\
\text { patterns, mindfulness }\end{array}$ \\
\hline $\begin{array}{l}\text { 3. Adapted listening } \\
\text { environment }\end{array}$ & $\begin{array}{l}\text { Hearing strategies, devices, } \\
\text { relaxation }\end{array}$ & $\begin{array}{l}\text { Relaxation exercise, trying a } \\
\text { new hearing strategy }\end{array}$ \\
\hline $\begin{array}{l}\text { 4. Approaching } \\
\text { aversive situations }\end{array}$ & Acceptance & $\begin{array}{l}\text { Holding water in mouth, } \\
\text { monsters on bus metaphor }\end{array}$ \\
\hline $\begin{array}{l}\text { 5. Getting stuck in } \\
\text { thoughts }\end{array}$ & Psychoeducation, defusion & $\begin{array}{l}\text { Trying out any defusion } \\
\text { technique daily }\end{array}$ \\
\hline $\begin{array}{l}\text { 6. Your life in the } \\
\text { present }\end{array}$ & $\begin{array}{l}\text { Mindfulness, mindful } \\
\text { communication }\end{array}$ & $\begin{array}{l}\text { Mindfulness, applying } \\
\text { mindful communication } \\
\text { skills in real life }\end{array}$ \\
\hline 7. Life after treatment & Maintain gains & $\begin{array}{l}\text { Identify warning signs of } \\
\text { slipping in to old habits }\end{array}$ \\
\hline 8. Tying it all together & $\begin{array}{l}\text { Experiential avoidance, } \\
\text { values, summary }\end{array}$ & $\begin{array}{l}\text { Life metaphor, evaluating } \\
\text { progress made, rewards }\end{array}$ \\
\hline
\end{tabular}

Besides engaging with the treatment material each week, participants also were tasked with completing the HHIE-S each week. The secondary measures were only administered pre- and post-treatment. These were the Patient 
Health Questionnaire 9 [PHQ-9] to measure depressive symptoms (Kroenke, Spitzer, \& Williams, 2001), the Generalized Anxiety Disorder 7 [GAD-7] to measure symptoms of anxiety (Spitzer, Kroenke, Williams, \& Löwe, 2006) and the Quality of Life Inventory [QOLI] to measure quality of life (Frisch et al., 1992).

Main outcome was analysed with a linear mixed effect model with maximumlikelihood analysis and using the intent-to-treat principle with all randomized participants also being included in the analysis. Treatment effect was evaluated by examining the fixed effect on the linear slope (time $\mathrm{x}$ group).

\section{Results and discussion}

On the main outcome measure, the HHIE-S, we found a significant interaction effect between time and group, $B=-0.58,95 \%$ CI $[-1.03,-.14]$, $t(53.88)=-2.64 p=.01$. This is illustrated in Figure 2. This means that the intervention group improved 0.58 scores more on the HHIE-S per week of treatment than the control group. This corresponds to a large effect size, Cohen's $d=0.93$ 95\% CI [0.24, 1.63].

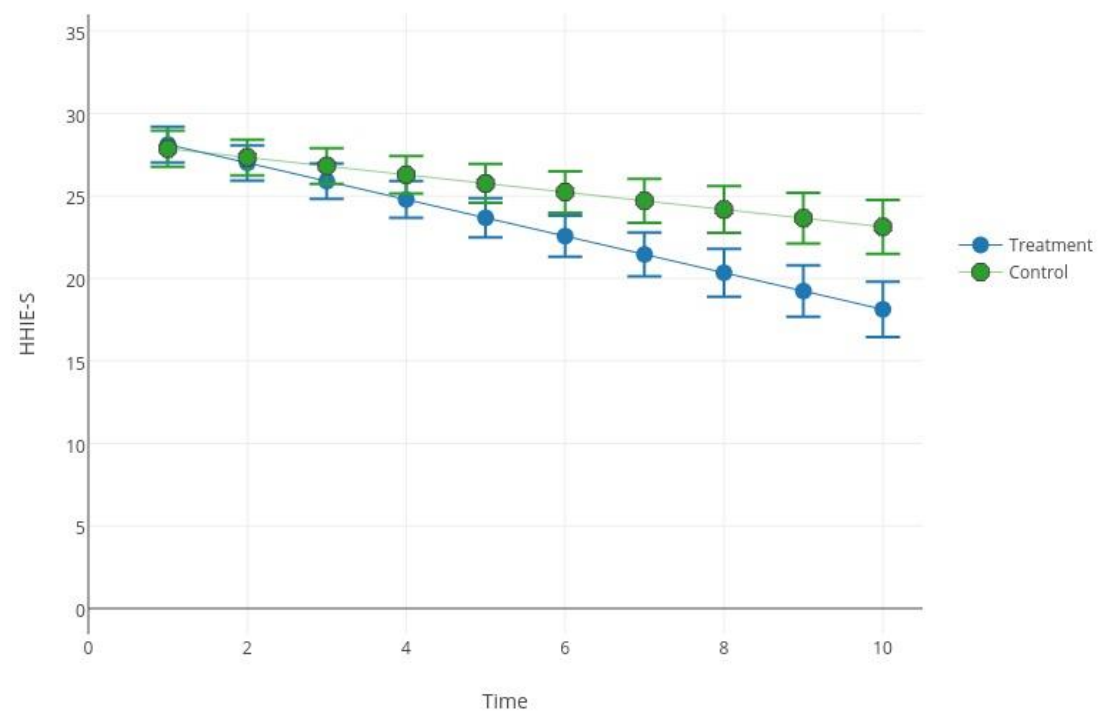

Figure 2. Weekly estimated means and standard errors for the HHIE-S 
Further mixed-model's analysis of secondary measures also revealed that the intervention group did better at post treatment than the control group. As can be seen in Table 8, both groups seemed to improve over time. However, the treatment group improved more on the PHQ-9, $B=-2.97,95 \%$ CI $[-5.81$, $-.13], t(51.82)=-2.1 p=.04$ and on the QOLI, $B=1.12,95 \%$ CI [.16, 2.08], $t(45.14)=2.34, p=.02$

Table 8. Observed means and standard deviations on the main and secondary outcome measures divided by group

\begin{tabular}{|c|c|c|c|c|c|c|}
\hline \multirow{2}{*}{$\begin{array}{l}\text { Measure and } \\
\text { condition }\end{array}$} & \multicolumn{3}{|c|}{ Pre } & \multicolumn{3}{|c|}{ Post } \\
\hline & Mean & SD & $\mathrm{n}$ & Mean & SD & $\mathrm{n}$ \\
\hline \multicolumn{7}{|l|}{ HHIE-S } \\
\hline Treatment & 28.71 & 6.42 & 31 & 19.68 & 7.49 & 19 \\
\hline Control & 29.33 & 5.18 & 30 & 24.25 & 8.91 & 24 \\
\hline \multicolumn{7}{|l|}{ PHQ-9 } \\
\hline Treatment & 9.26 & 5.2 & 31 & 3.89 & 3.71 & 19 \\
\hline Control & 7.4 & 4.32 & 30 & 5.04 & 2.85 & 24 \\
\hline \multicolumn{7}{|l|}{ GAD-7 } \\
\hline Treatment & 6.42 & 4.75 & 31 & 3.21 & 3.36 & 19 \\
\hline Control & 5.6 & 4.42 & 30 & 3.67 & 3.23 & 24 \\
\hline \multicolumn{7}{|l|}{ QOLI } \\
\hline Treatment & 1.15 & 1.65 & 31 & 2.65 & 1.57 & 19 \\
\hline Control & 1.4 & 1.39 & 30 & 1.87 & 1.71 & 24 \\
\hline
\end{tabular}

Note: HHIE-S = Hearing Handicap Inventory for the Elderly Screening Version; PHQ-9 = Patient Health Questionnaire 9-item scale; GAD-7 = Generalized Anxiety Disorder 7-item scale; QOLI = Quality of Life Inventory.

The differences between groups at endpoint corresponds to a medium effect size for depressive symptoms, Cohen's $d=0.61,95 \%$ CI $[.04,1.19]$ and a large effect for quality of life, $d=.88,95 \%$ CI $[0.14,1.61]$. There were no significant differences on anxiety symptoms.

Overall, this means that this first study of acceptance-based internet delivered guided self-help treatment for distress associated with hearing loss largely was successful. Previously, unguided computerizes CBT also indicated that this kind of approach might be promising (Garnefski \& Kraaij, 2012). In this study, large to medium-sized effects of treatments were found for 
psychosocial handicap, depressive symptoms and quality of life. Especially as the sample size was on the smaller side, there is a need for replication. Such replication should preferably be performed by researchers unrelated to the current team, before drawing conclusions on the appropriateness of trying this kind of treatment in regular care. 


\section{General discussion}

\section{Main findings and conclusions}

This thesis aimed at studying three different aspects of helping people move from detection of hearing issues to completed rehabilitation. This was done by studying hearing screening procedures on the internet, measure acceptance among people with hearing loss, and treating psychological distress caused by hearing loss.

Both Study I and Study II were internet-based hearing screenings. In the first study, a speech-in-noise test was adapted and evaluated for internet use. The procedure seemed to be acceptable to the participants. There were several differences between those who passed and those who failed the hearing test; those who failed reported more problems with their hearing in all kinds of hearing situations measured by the self-report questionnaire. Further, their ability to correctly judge if pairs of words rhymed or not was also lower, in line with the hypothesis that phonological representation skills deteriorates from hearing loss. However, in contrast to other studies we found no difference in ratings of quality of life.

The second screening study featured an improved hearing test, self-report measures of anxiety and depression, and an additional test of cognitive performance (the Trail Making Test), in a sample that was several times larger than in Study I. There were slightly more participants that failed the hearing test than in the previous study, $19,0 \%$ here vs $16.7 \%$ in Study I. Having a higher degree of education, being younger than 65 years old, and being a woman, was associated with passing the hearing test. In a multivariate analysis, we found no significant contribution of anxiety, depression, quality of life, or rhyme-judgment ability in relation to failing the hearing test. These results were surprising, as they go against the findings of several previous studies.

The reasons for these surprising findings are hard to explain with certainty. When it comes to the rhyme-judgment task, the inclusion of the TMT in the model is a likely explanation for its relative unimportance. Although previously theorized to load on separate cognitive abilities (Alloway et al., 
2004) the result of our study does not support that notion. In a separate publication, we further analysed the relationship between the TMT and hearing ability in noise (Ellis et al., 2016). We found that processing speed accounted for a large portion of the contribution of the TMT in relationship to hearing performance, and that the "higher" cognitive functions that are loaded in the more complex TMT presentations have a very small, but significant, relationship to hearing performance. This is interesting, as the rhyme-judgment task had stimuli that only was presented for two seconds for each word-pair. This might mean that both tests more than anything else were measuring processing speed, and that the continuous nature of TMT responses was a better measure for processing speed rather than the pass/fail structure of the rhyme-judgement task. Processing speed is in its own right a correlate to both working memory capacity and hearing performance (Larsby, Hällgren, \& Lyxell, 2008; Pichora-Fuller et al., 2016).

In Study II, there was no significant relationship between anxiety and depression in a multivariate context. A possible explanation for this the differences in samples between Study II and previous work where both anxiety (Carlsson et al., 2014; Contrera et al., 2017; Jones et al., 1984) and depression (Keidser \& Seeto, 2017; Keidser, Seeto, Rudner, Hygge, \& Rönnberg, 2015) has been linked to hearing ability. In the present study, people were recruited by advertisement, largely did not a have a clinically meaningful hearing loss, and were highly educated. This means that the current sample was quite different from that from other studies in which this effect has been noted. Another possibility in the deviation of the results is that this kind of test attracts the group that use to be called the 'worried well' (Wagner \& Curran, 1984) as the univariate analysis indicated that participants with more anxiety did better on the hearing test. Another explanation might lie in the measures used. While Carlsson et al. used an established questionnaire to measure anxiety and depression among those with severe to profound hearing loss, other comparable studies have used only 3 to 4 items as proxies of depression and anxiety and not established questionnaires. This means that those studies probably have less accuracy in measurement than the current one. 
In very large studies ( $\mathrm{N}>40000)$, where symptoms of anxiety and depression in relation to hearing have been measured in Norway (Kvam, Loeb, \& Tambs, 2007) or the United Kingdom (Keidser, Seeto, Rudner, Hygge, Rönnberg, et al., 2015) there has indeed been a relationship between hearing and psychological distress. A treatment for this group was developed as Study IV. The intervention offered in this study was developed from an acceptancebased approach, but there was no satisfactory measure of hearing-related acceptance available. Therefore, Study III concerns the development of such a scale.

The measure of acceptance, the HAQ, had two possible factor structures. The three-factor solution had somewhat better values in most tests of its psychometrical properties. The downside to a three-factor solution is that it is a bit harder to score and interpret, and that the internal consistency is suboptimal. We therefore recommended the use of the two-factor solution. Even though there was room for some improvements when it comes to its psychometrics, the HAQ did show promising properties. For example, it seemed to measure a unique aspect of the psychological hardships involved for people with hearing loss, beyond anxiety and depression. It was also more strongly related to hearing disability than measured hearing performance. Perceived hearing disability is important, not only in its own right, but also through being related to lower quality of life in a 10-year prospective study even when accounting for objective hearing performance (Gopinath et al., 2012). Thus, efforts to lessen hearing disability might have positive longterm consequences.

This gives weight to the argument that the detrimental impact of hearing loss on an individual can to a certain degree be modified by how the affected person perceive the hearing loss as an hindrance and what coping behaviours are used (Gomez \& Madey, 2001; Lehane et al., 2017). This phenomenon has also, to varying degrees, been observed in chronic pain research, which is a field where much of the development of acceptance as a key concept in living with a chronic condition has taken place (McCracken, 1998; Viane et al., 2003). 
The observation that hearing loss acceptance seems to play an important role in hearing disability is not in itself directly helpful for those affected. From a pragmatic point of view - to inform the hearing rehabilitation process relevant factors must also be modifiable to be helpful. That is, hearing loss acceptance should not be a fixed trait in an individual but rather more reflecting of a state that can be altered.

There is overwhelming evidence for the fact that psychological treatments, especially those from the cognitive-behavioural tradition of which ACT is part are helpful for a range of psychiatric and somatic conditions (Butler, Chapman, Forman, \& Beck, 2006; Cuijpers, Smit, Bohlmeijer, Hollon, \& Andersson, 2010; Hofmann, Asnaani, Vonk, Sawyer, \& Fang, 2012). Although most meta-analysis and reviews of meta-analysis are favourable, there is still work to be done. For example, a recent umbrella review found several issues with published results such as an excess of significant $p$-values and small-study effects where large and more rigorous trials yield smaller effects than those with a smaller sample size (Dragioti, Karathanos, Gerdle, \& Evangelou, 2017).

Recent years has seen an increased interest in to what extent published results actually can be trusted in relation to real world effects (Alexander et al., 2012). At least for the field of psychology, many results are hard to replicate with comparable effect sizes as the original studies (Aarts et al., 2015). One partial solution to this is through an open science ideal where increased openness in sharing data, pre-registering studies and increasing transparency are recommended actions (Nosek et al., 2015). Another way of improving studies in the field of clinical psychology is to not only study if treatment $X$ is effective for condition $\mathrm{Y}$, but also studying the processes and mechanism involved on how change comes about as a vehicle for further understanding and improvement of treatments.

One way of understanding how positive outcomes are reached is to perform mediation analysis (Baron \& Kenny, 1986). There are many intricacies involved with studying mediation (Zhao, Lynch, \& Chen, 2010), but in short it involves studying how a variable accounts for the relationship between the independent and the dependent variable (Kazdin, 2007). In the field of 
psychological treatments, this is achieved by measuring a construct thought to be of importance as a mechanism of change at one or several points in time between treatment start and the end of treatment.

Preliminary results of the use of the HAQ (reported in Study III) as a weekly process measure in Study IV did indicate that it indeed seem to work as a mediator of change. That is, change in ratings of hearing related acceptance during treatment influenced to what degree the participants rated improvements on hearing disability (Bergwall \& Hansson-Malmöf, 2014). This means that not only does the HAQ seem to measure a unique aspect of negative psychological impact from hearing loss, it also indicates that it is possible to increase this kind of psychological acceptance through targeted treatment, and that improvements in this regard is related to less perceived hearing disability.

Beyond large effects on the main outcome measure, the HHIE-S, Study IV also seemed to be effective on secondary measures. This meant that the treatment group improved on measures of quality of life and depression, more than the control group. There was no group difference on score of anxiety, which was a measure where those included in the study did not have that high ratings to begin with.

To summarize, Study IV used an acceptance-based form of online guided self-help for those with psychological distress and hearing loss. A study protocol was also published for this study (Molander et al., 2015). Experiences from previously published studies were considered, such as devoting one of the eight weeks of treatment to hearing tactics, inspired by Sundewall Thorén (2014). There were two main points that was emphasized in treatment, A) to increase valued activities, and B) to make sure that homework involved overt behaviour change. Further studies would hopefully involve a larger sample size, use an active control treatment, and focus on ways in which adherence to treatment might increase (as 12 out of 31 participants in the treatment arm did not answer post treatment measures).

The current thesis aimed at helping people with hearing loss move from detection of hearing issues to completed rehabilitation, for those with 
comorbid psychological distress. This was done by firstly studying internetbased hearing screening procedures, secondly by developing a measure of hearing loss acceptance, and thirdly by treating psychological distress among those with hearing loss with the use of an acceptance based approach.

Study I and II demonstrated the feasibility of internet-based hearing screenings with a Swedish speech-in-noise test, and described how poor performance on such a test is related to more self-rated hearing problems and lower scores on cognitive testing. It did however not affect ratings of quality of life. Although there was a simple association between hearing ability and anxiety, this finding did not remain significant in a multivariate context when considering demographical variables and cognitive ability.

Study III described the development and evaluation of a scale for measuring psychological acceptance of hearing loss, the HAQ. The psychometric properties were good to acceptable and the instrument measured a unique aspect of hearing related suffering. Further, the HAQ made a larger contribution to measures of hearing disability than depression, anxiety and measured hearing performance.

The final goal of the thesis was to treat psychological distress associated with hearing loss. This was attempted in Study IV. By using an eight-week long internet-based treatment, we demonstrated that this type of intervention can reduce self-rated hearing disability. The intervention group received treatment based on ACT, while the control group was put on wait-list. Further, the treatment also seemed to improve quality of life and lower depressive symptoms. 


\section{Limitations}

There are several limitations of the studies in this thesis. One limitation affecting all the studies is the makeup of the participants, where they were more highly educated than the average population.

Further, the hearing tests involved in Study I and II do not have the same accuracy as traditional measures of hearing loss has. We also saw that results differed for those using earphones in relation to those that, against recommendations, used speakers. In the worst case, this might mean that participants in need of seeking hearing health care might have been wrongly classified simply because of playback options. Further, hearing in noise tests can detect sensorineural hearing loss, but not conductive. This means that some people with an actual diagnosis will still pass the test, which certainly is worse than the other way around (that a person without hearing loss is recommended to contact an audiologist). While this consequence lies in the nature of screening procedures that prioritizes ease of access and affordability while lowering precision, this might mean that people who were ready to seek help put off hearing rehabilitation. To counter this, we recommended everyone at the end of the hearing test to still seek help if they had perceived serious issues with their hearing but this might not have been effective in all cases.

Although there are several weaknesses that could be pointed out for Study III and IV (most prominently the use of a single sample, and below optimal fit measures for the HAQ in Study III, and few participants and wait-list control in Study IV), I would like to point out another weakness on a higher level. In the Introduction, I mentioned Wilson and Jungners (1968) criteria for a successful screening program. One of the issues they raised was that there is no point in detecting a condition if one is not also able to provide a treatment for said condition. In the case of psychological acceptance, and treatments based on those principles, they are designed for use and delivery by therapists with training in $\mathrm{CBT}$ in general and $\mathrm{ACT}$ in particular.

Admittedly, there are people with that kind of background working in audiological clinics. For those that do, and are treating tinnitus with CBT or $\mathrm{ACT}$, the introduction of similar treatments as in this thesis would not be hard 
(barring of course that the necessary replications are first performed). However, those people are quite rare and the clinicians most patient meet are audiologists. Nevertheless, for most patients there is no easy way to receive proper psychological treatment as a part of their rehabilitation, and it is unreasonable to expect that there would suddenly be a large influx of psychologists hired at audiologist clinics. Therefore, perhaps a treatment that more naturally could be part of the treatment activities already offered would have had better prospects of improving the situation for those affected.

Another limitation to stress in the current thesis is that primarily biological (objective hearing performance) and psychological (acceptance, distress, cognition) factors were studied. Little attention has been given to social or environmental aspects, even though these surely have role to play. For instance, some argue that disability only exists in relation to current environment or social conditions (Söder, 2009). By placing all explanatory variables on an individual level, it can also be interpreted as it is solely up to the individual to resolve the negative consequences of the situation, and that those who are not able to do so are personally to blame for their condition when in fact social and environmental factors have a huge role to play. 


\section{Future directions}

The title of the current thesis, from detection to intervention, hints at the prospect of studying the complete patient journey from detection to resolution (ignoring the lack of restorative treatments). This was not possible, an indeed not the goal, of the current thesis. However, if one envisions a day where a person can receive almost all their audiological rehabilitation online there are first several issues to resolve that has not yet been studied to my knowledge.

Instead, there are several studies of each component in such a model. For example, there are studies of hearing tests online (Smits et al., 2006), support systems to help in the rehabilitation process after one has been to the audiologist (Brännström et al., 2015) and studies of online rehabilitation for hearing aid users (Sundewall Thorén et al., 2014). There are also initial looks on the motivational process involved in advancing in hearing rehabilitation uptake (Ingo, Brännström, Andersson, Lunner, \& Laplante-Lévesque, 2016; Laplante-Lévesque, Brännström, Ingo, Andersson, \& Lunner, 2014), and a study protocol on how motivation to seek help might be increased (Weineland et al., 2015). There is also a study on how to help those that suffer psychological distress via the internet (Study IV).

Yet, these studies are not integrated with one another. We know that most of those who fail a hearing screening actually do nothing about it (Meyer et al., 2011). An interesting development would be a research program were those who fail an internet-based hearing screening are followed for a longer period, where those in need are motivated to seek help, and where the results of their screening influence the kind of interventions they receive (such as their cognitive ability and their psychological well-being). Answers from such a study would also allow us to finally answer if indeed online hearing screening procedures are cost effective and if they should be offered at all.

Beyond that, there is a need for replication of most of the findings. The use and confirmation of the properties of the HAQ from another sample would be valuable. It would also be interesting to see if the kind of treatment offered in Study IV would work in traditional face-to-face treatment. We were also quick to try the treatment package in a RCT. It would be interesting to perform studies of steps usually taken before a RCT is performed, such as doing more 
qualitative work on a much smaller sample of initial participants. The proposed mechanisms of change would also be nice to study in a more experimental setting. Further, it would be valuable to know if the TMT results might influence hearing aid fitting, use and satisfaction.

Beyond these more specific research questions, the overall potential importance of an acceptance based behavioural approach to address the increasing prevalence of hearing disorders is in need of further systematic study. 


\section{References}

Aarts, A. A., Anderson, J. E., Anderson, C. J., Attridge, P. R., Attwood, A., Axt, J., ... Zuni, K. (2015). Estimating the reproducibility of psychological science. $\quad$ Science, $349(6251)$. http://doi.org/10.1126/science.aac4716

Aazh, H., \& Moore, B. C. J. (2017). Audiological Rehabilitation for Facilitating Hearing Aid Use: A Review. Journal of the American Academy of Audiology, 28(3), 248-260. http://doi.org/10.3766/jaaa.16035

Alexander, A., Barnett-Cowan, M., Bartmess, E., Bosco, F. A., Brandt, M., Carp, J., ... Vianello, M. (2012). An open, large-scale, collaborative effort to estimate the reproducibility of psychological science. Perspectives on Psychological Science, 7(6), 657-660. http://doi.org/10.1177/1745691612462588

Alloway, T. P., Gathercole, S. E., Willis, C., \& Adams, A. M. (2004). A structural analysis of working memory and related cognitive skills in young children. Journal of Experimental Child Psychology, 87(2), 85106. http://doi.org/10.1016/j.jecp.2003.10.002

Andersson, G. (2016). Internet-Delivered Psychological Treatments, (November 2015), 1-23. http://doi.org/10.1146/annurev-clinpsy021815-093006

Andersson, G. (2018). Internet interventions: Past, present and future. Internet Interventions, 12(April), 181-188. http://doi.org/10.1016/j.invent.2018.03.008

Andersson, G., Green, M., \& Melin, L. (1997). Behavioural hearing tactics: a controlled trial of a short treatment programme. Behaviour Research and Therapy, 35(6), 523-530. http://doi.org/10.1016/S00057967(97)00009-0

Andersson, G., \& Hedman, E. (2013). Effectiveness of guided internet-based cognitive behavior therapy in regular clinical settings. Verhaltenstherapie, 23(3), 140-148. http://doi.org/10.1159/000354779

Andersson, G., Lindvall, N., Hursti, T., \& Carlbring, P. (2002). Hypersensitivity to sound (hyperacusis): a prevalence study conducted via the internet and post. International Journal of Audiology, 41(8), 545554. http://doi.org/10.3109/14992020209056075

Andersson, G., Melin, L., Scott, B., \& Lindberg, P. (1994). Behavioural Counselling for Subjects with Acquired Hearing Loss A New Approach to Hearing Tactics. Scandinavian Audiology, 23(4), 249-256. http://doi.org/10.3109/01050399409047516

Andersson, G., Melin, L., Scott, B., \& Lindberg, P. (1995). An evaluation of a behavioural treatment approach to hearing impairment. Behaviour 
Research and Therapy, 33(3), 283-292. http://doi.org/10.1016/00057967(94)00040-Q

Andersson, G., Strömgren, T., Ström, L., \& Lyttkens, L. (2002). Randomized controlled trial of internet-based cognitive behavior therapy for distress associated with tinnitus. Psychosomatic Medicine, 64(5), 810-816. http://doi.org/10.1097/01.PSY.0000031577.42041.F8

Andersson, G., \& Titov, N. (2014). Advantages and limitations of Internet based interventions for common mental disorders. World Psychiatry, 13(2), 4-11. http://doi.org/10.1002/wps.20083

Andersson, G., \& Willebrand, M. (2003). What is coping? A critical review of the construct and its application in audiology. International Journal of Audiology, 42 Suppl 1(I), $\quad$ S97-103. http://doi.org/10.3109/14992020309074630

Andersson, U. (2002). Deterioration of the phonological processing skills in adults with an acquired severe hearing loss. European Journal of Cognitive Psychology, 14:3(April 2012), 335-352.

Andersson, U., \& Lyxell, B. (1998). Phonological Deterioration in Adults with an Acquired Severe Hearing Impairment. Scandinavian Audiology, 27(4), 93-100.

Arch, J., Eifert, G. H., Davies, C., Plumb Vilardaga, J. C., Rose, R. D., \& Craske, M. G. (2012). Randomized clinical trial of cognitive behavioral therapy (CBT) versus acceptance and commitment therapy (ACT) for mixed anxiety disorders. J Consult Clin Psychol, 80(5), 750-765. http://doi.org/10.1037/a0028310

Arlinger, S., Lunner, T., Lyxell, B., \& Pichora-Fuller, M. K. (2009). The emergence of cognitive hearing science. Scandinavian Journal of Psychology, 50(5), 371-84. http://doi.org/10.1111/j.14679450.2009.00753.x

Arlinger, S., Nordqvist, P., \& Öberg, M. (2017). International outcome inventory for hearing aids: Data from a large Swedish quality register database. American Journal of Audiology, 26(3S), 443-450. http://doi.org/10.1044/2017_AJA-16-0123

Armijo Olivo, S., Macedo, L. G., Gadotti, I. C., Fuentes, J., Stanton, T., \& Magee, D. J. (2007). Scales to Assess the Quality of Randomized Controlled Trials: A Systematic Review. Physical Therapy, 88(2).

Axelsson, A., \& Ringdahl, A. (1989). Tinnitus-a study of its prevalence and characteristics. British Journal of Audiology, 23, 53-62.

Barnes-Holmes, D. (2000). Behavioral Pragmatism : No Place for Reality and Truth, The Behavioral Analyst, 2(2), 191-202.

Barnes-Holmes, D. (2005). Not Antirealism But A-Ontological. Behavior \& Philosophy, 67-80.

Baron, R. M., \& Kenny, D. A. (1986). The moderator-mediator variable 
distinction in social psychological research: conceptual, strategic, and statistical considerations. Journal of Personality and Social Psychology, 51(6), 1173-1182.

Bergwall, K., \& Hansson-Malmöf, J. (2014). Förändingsprocessen $i$ Acceptance and Commitment Therapy för personer med hörselnedsättning. (Master's thesis). Linköpings Universitet, Linköping. Beukes, E. W., Baguley, D. M., Allen, P. M., Manchaiah, V., \& Andersson, G. (2017). Audiologist-Guided Internet-Based Cognitive Behavior Therapy for Adults With Tinnitus in the United Kingdom. Ear and Hearing, 1. http://doi.org/10.1097/AUD.0000000000000505

Boeschen Hospers, J. M., Smits, N., Smits, C., Stam, M., Terwee, C. B., \& Kramer, S. E. (2016). Reevaluation of the Amsterdam Inventory for Auditory Disability and Handicap Using Item Response Theory. Journal of Speech Language and Hearing Research, 59(2), 373. http://doi.org/10.1044/2015_JSLHR-H-15-0156

Brännström, K. J., Öberg, M., Ingo, E., Månsson, K. N., Lunner, T., \& Laplante-Lévesque, A. (2015). The Process of Developing an InternetBased Support System for Audiologists and First-Time Hearing Aid Clients. American Journal of Audiology, 24, 320-324. http://doi.org/10.1044/2015

Butler, A. C., Chapman, J. E., Forman, E. M., \& Beck, A. T. (2006). The empirical status of cognitive-behavioral therapy: A review of metaanalyses. Clinical Psychology Review, 26(1), 17-31. http://doi.org/10.1016/j.cpr.2005.07.003

Byrne, D. (1981). Clinical issues and options in binaural hearing aid fitting. Ear and Hearing, 2(5), 187-193. http://doi.org/10.1097/00003446198109000-00002

Cardon, G., \& Sharma, A. (2018). Somatosensory Cross-Modal Reorganization in Adults With Age-Related, Early-Stage Hearing Loss. Frontiers in Human Neuroscience, 12(May), 172. http://doi.org/10.3389/fnhum.2018.00172

Carlbring, P., Andersson, G., Cuijpers, P., Riper, H., \& Hedman-Lagerlöf, E. (2018). Internet-based vs. face-to-face cognitive behavior therapy for psychiatric and somatic disorders: an updated systematic review and meta-analysis. Cognitive Behaviour Therapy, 47(1), 1-18. http://doi.org/10.1080/16506073.2017.1401115

Carlbring, P., Brunt, S., Bohman, S., Austin, D., Richards, J., Öst, L.-G., \& Andersson, G. (2007). Internet vs. paper and pencil administration of questionnaires commonly used in panic/agoraphobia research. Computers in Human Behavior, 23(3), 1421-1434. http://doi.org/10.1016/j.chb.2005.05.002

Carlsson, P.-I., Hjaldahl, J., Magnuson, A., Ternevall, E., Edén, M., 
Skagerstrand, A., \& Jönsson, R. (2014). Severe to profound hearing impairment: quality of life, psychosocial consequences and audiological rehabilitation. Disability and Rehabilitation, 1-8. http://doi.org/10.3109/09638288.2014.982833

Chung, S.-D., Hung, S.-H., Lin, H.-C., \& Sheu, J.-J. (2015). Association between sudden sensorineural hearing loss and anxiety disorder: a population-based study. European Archives of Oto-Rhino-Laryngoly, 272(10), 2673-2678. http://doi.org/10.1007/s00405-014-3235-8

Ciorba, A., Bianchini, C., Pelucchi, S., \& Pastore, A. (2012). The impact of hearing loss on the quality of life of elderly adults. Clinical Interventions in Aging, 139(5-6), 159. http://doi.org/10.2147/CIA.S26059

Clark, J. G., Maatman, C., \& Gailey, L. (2012). Moving Patients Forward : Motivational Engagement. Seminars in Hearing, 33(1), 35-45.

Classon, E., Rudner, M., \& Rönnberg, J. (2013). Working memory compensates for hearing related phonological processing deficit. Journal of Communication Disorders, 46(1), 17-29. http://doi.org/10.1016/j.jcomdis.2012.10.001

Contrera, K. J., Betz, J., Deal, J., Choi, J. S., Ayonayon, H. N., Harris, T., ... Lin, F. R. (2017). Association of Hearing Impairment and Anxiety in Older Adults. Journal of Aging and Health, 29(1), 172-184. http://doi.org/10.1177/0898264316634571

Cuijpers, P., Smit, F., Bohlmeijer, E., Hollon, S. D., \& Andersson, G. (2010). Efficacy of cognitive-behavioural therapy and other psychological treatments for adult depression: Meta-analytic study of publication bias. British Journal of Psychiatry, 196(3), 173-178. http://doi.org/10.1192/bjp.bp.109.066001

Dahl, J., \& Lundgren, T. (2006). Living Beyond Your Pain. Oakland: New Harbinger Publications.

Dalton, D. S., Cruickshanks, K. J., Klein, B. E. K., Klein, R., Wiley, T. L., \& Nondahl, D. M. (2003). The Impact of Hearing Loss on Quality of Life in Older Adults, 43(5), 661-668.

Davis, A., McMahon, C. M., Pichora-Fuller, K. M., Russ, S., Lin, F., Olusanya, B. O., ... Tremblay, K. L. (2016). Aging and hearing health: The life-course approach. Gerontologist, 56(March), S256-S267. http://doi.org/10.1093/geront/gnw033

Davis, A., Smith, P., Ferguson, M., Stephens, D., \& Gianopoulos, I. (2007). Acceptability, benefits and costs of early screening for hearing disability study tests and models.pdf. Health Technology Assessment, 11(42). http://doi.org/10.3310/hta11420

Demeester, K., Topsakal, V., Hendrickx, J., Fransen, E., Laer, L. Van, Camp, G. Van, ... Wieringen, A. Van. (2012a). Hearing Disability Measured by the Speech, Spatial, and Qualities of Hearing Scale in Clinically 
Persons, and Disability Screening by Means of a Reduced SSQ (the SSQ5). Ear \& Hearing, 33(5), 615-626.

Demorest, M. E., \& Erdman, S. (1986). Scale Composition and item analysis of the communication profile for the hearing impaired. Journal of Speech and Hearing Research, 29(December), 515-535.

DiClemente, C. C., \& Hughes, S. O. (1990). Stages of change profiles in outpatient alcoholism treatment. Journal of Substance Abuse, 2(2), 217 35.

Dragioti, E., Karathanos, V., Gerdle, B., \& Evangelou, E. (2017). Does psychotherapy work? An umbrella review of meta-analyses of randomized controlled trials. Acta Psychiatrica Scandinavica, 136(3), 236-246. http://doi.org/10.1111/acps.12713

Elberling, C., \& Worsöe, K. (2006). När ljuden blir svagare - om hörsel och hörapparater. Herlev: Bording A/S.

Ellis, R. J., Molander, P., Rönnberg, J., Lyxell, B., Andersson, G., \& Lunner, T. (2016). Predicting speech-in-noise recognition from performance on the trail making test: Results from a large-scale internet study. Ear and Hearing, 37(1). http://doi.org/10.1097/AUD.0000000000000218

Fay, R. R., \& Popper, A. N. (2000). Evolution of hearing in vertebrates: The inner ears and processing. Hearing Research, 149(1-2), 1-10. http://doi.org/10.1016/S0378-5955(00)00168-4

Ferguson, M. A., \& Henshaw, H. (2015). Auditory training can improve working memory, attention, and communication in adverse conditions for adults with hearing loss. Frontiers in Psychology, 6(JAN), 1-7. http://doi.org/10.3389/fpsyg.2015.00556

Ferguson, M., Brandreth, M., Brassington, W., Leighton, P., \& Wharrad, H. (2016). A Randomized Controlled Trial to Evaluate the Benefits of a Multimedia Educational Program for First-Time Hearing Aid Users. Ear and Hearing, 37(2), 123-136. http://doi.org/10.1097/AUD.0000000000000237

Forskningsinstitutet Hörselbron. (2012). Kvalitetsregister hörselrehabilitering för vuxna Årsrapport 2012.

Frisch, M. B., Cornell, J., Villanueva, M., \& Retzlaff, P. J. (1992). Clinical validation of the Quality of Life Inventory. A measure of life satisfaction for use in treatment planning and outcome assessment. Psychological Assessment, 4(1), 92-101. http://doi.org/10.1037//1040-3590.4.1.92

Garnefski, N., \& Kraaij, V. (2012). Effects of a Cognitive Behavioral Selfhelp program on emotional problems for people with acquired hearing loss: a randomized controlled trial. Journal of Deaf Studies and Deaf Education, 17(1), 75-84. http://doi.org/10.1093/deafed/enr020

Gatehouse, S., Naylor, G., \& Elberling, C. (2006). Linear and nonlinear hearing aid fittings - 2. Patterns of candidature. International Journal of 
Audiology, 45(3), 153-171. http://doi.org/10.1080/14992020500429484

Gelfand, S. A. (2009). Essentials of Audiology (Third edit). New York: Thieme Medical Publishers.

Gomez, R. G., \& Madey, S. F. (2001). Coping-With-Hearing-Loss Model for

Older Adults. The Journals of Gerontology Series B: Psychological Sciences and Social Sciences, 56(4), P223-P225. http://doi.org/10.1093/geronb/56.4.P223

Gopinath, B., Schneider, J., Hickson, L., McMahon, C. M., Burlutsky, G., Leeder, S. R., \& Mitchell, P. (2012). Hearing handicap, rather than measured hearing impairment, predicts poorer quality of life over 10 years in older adults. Maturitas, 72(2), 146-51. http://doi.org/10.1016/j.maturitas.2012.03.010

Gregg, J. a, Callaghan, G. M., Hayes, S. C., \& Glenn-Lawson, J. L. (2007). Improving diabetes self-management through acceptance, mindfulness, and values: a randomized controlled trial. Journal of Consulting and Clinical Psychology, 75(2), 336-43. http://doi.org/10.1037/0022006X.75.2.336

Gustafsson, K., Backenroth-Ohsako, G., Rosenhall, U., Ternevall-Kjerulf, E., Ulfendahl, M., \& Alexanderson, K. (2011). Future risk for disability pension among people with sickness absence due to otoaudiological diagnoses: a population-based cohort study with a 12-year follow-up. Scandinavian Journal of Public Health, 39(5), 501-7. http://doi.org/10.1177/1403494811399652

Hallberg, L. R. M., Hallberg, U., \& Kramer, S. E. (2008). Self-reported hearing difficulties, communication strategies and psychological general well-being (quality of life) in patients with acquired hearing impairment. Disability and Rehabilitation, 30(3), 203-12. http://doi.org/10.1080/09638280701228073

Harris, R., Sawaya, G. F., Moyer, V. A., \& Calonge, N. (2011). Reconsidering the criteria for evaluating proposed screening programs: Reflections from 4 current and former members of the U.S. preventive services task force. Epidemiologic Reviews, 33(1), 20-35. http://doi.org/10.1093/epirev/mxr005

Harrison Bush, A. L., Lister, J. J., Lin, F. R., Betz, J., \& Edwards, J. D. (2015). Peripheral Hearing and Cognition. Ear and Hearing, 36(4), 395-407. http://doi.org/10.1097/AUD.0000000000000142

Hartley, D., Rochtchina, E., Newall, P., Golding, M., \& Mitchell, P. (2010). Use of Hearing Aids and Assistive Listening Devices in an Older Australian Population. Journal of the American Academy of Audiology, 21(10), 642-653. http://doi.org/10.3766/jaaa.21.10.4

Hayes, S. C., Levin, M. E., Plumb-Vilardaga, J., Villatte, J. L., \& Pistorello, J. (2011). Acceptance and Commitment Therapy and Contextual 
Behavioral Science: Examining the Progress of a Distinctive Model of Behavioral and Cognitive Therapy. Behavior Therapy. http://doi.org/10.1016/j.beth.2009.08.002

Hayes, S. C., Luoma, J. B., Bond, F. W., Masuda, A., \& Lillis, J. (2006). Acceptance and commitment therapy: model, processes and outcomes. Behaviour Research and Therapy, 44(1), 1-25. http://doi.org/10.1016/j.brat.2005.06.006

Hayes, S. C., Strosahl, K., \& Wilson, K. G. (1999). Acceptance and Commitment Therapy: An experiential approach to behavior change. New York: Guilford Press.

Hayes, S. C., Villatte, M., Levin, M., \& Hildebrandt, M. (2011). Open, aware, and active: contextual approaches as an emerging trend in the behavioral and cognitive therapies. Annual Review of Clinical Psychology, 7, 14168. http://doi.org/10.1146/annurev-clinpsy-032210-104449

Hayes, S. C., Wilson, K. G., Gifford, E. V, Follette, V. M., \& Strosahl, K. (1996). Experimental avoidance and behavioral disorders: a functional dimensional approach to diagnosis and treatment. Journal of Consulting and Clinical Psychology, 64(6), 1152-1168. http://doi.org/10.1037/0022-006X.64.6.1152

Heinrich, A., Henshaw, H., \& Ferguson, M. A. (2015). The relationship of speech intelligibility with hearing sensitivity, cognition, and perceived hearing difficulties varies for different speech perception tests. Frontiers in Psychology, 6(June), 782. http://doi.org/10.3389/fpsyg.2015.00782

Henshaw, H., Clark, D. P. a, Kang, S., \& Ferguson, M. a. (2012). Computer Skills and Internet Use in Adults Aged 50-74 Years: Influence of Hearing Difficulties. Journal of Medical Internet Research, 14(4), e113. http://doi.org/10.2196/jmir.2036

Hesser, H., Gustafsson, T., Lundén, C., Henrikson, O., Fattahi, K., Johnsson, E., ... Andersson, G. (2012). A randomized controlled trial of Internetdelivered cognitive behavior therapy and acceptance and commitment therapy in the treatment of tinnitus. Journal of Consulting and Clinical Psychology, 80(4), 649-61. http://doi.org/10.1037/a0027021

Hesser, H., Weise, C., Westin, V. Z., \& Andersson, G. (2011). A systematic review and meta-analysis of randomized controlled trials of cognitivebehavioral therapy for tinnitus distress. Clinical Psychology Review, 31(4), 545-553. http://doi.org/10.1016/j.cpr.2010.12.006

Hickson, L., Worrall, L., \& Scarinci, N. (2007). A Randomized Controlled Trial Evaluating the Active Communication Education Program for Older People with Hearing Impairment. Ear and Hearing, 28(2), 212230. http://doi.org/10.1097/AUD.0b013e31803126c8

Hoff, M., Tengstrand, T., Sadeghi, A., Skoog, I., \& Rosenhall, U. (2018). Improved hearing in Swedish 70-year olds - a cohort comparison over 
more than four decades (1971-2014). Age and Ageing, (April), 437-444. http://doi.org/10.1093/ageing/afy002

Hofmann, S. G., Asnaani, A., Vonk, I. J. J., Sawyer, A. T., \& Fang, A. (2012). The efficacy of cognitive behavioral therapy: a review of meta-analyses. Cognitive Therapy Research, 36(5), 427-440. http://doi.org/10.1007/s10608-012-9476-1.The

Hogan, A., O'Loughlin, K., Miller, P., \& Kendig, H. (2009). The health impact of a hearing disability on older people in Australia. Journal of Aging and Health, 21(8), 1098-111. http://doi.org/10.1177/0898264309347821

Hornsby, B. W. Y. (2013). The effects of hearing aid use on listening effort and mental fatigue associated with sustained speech processing demands. Ear and Hearing, 34(5), 523-34. http://doi.org/10.1097/AUD.0b013e31828003d8

Hörselskadades Riksförbund. (2017). Hörselskadade $i$ siffror 2017. Stockholm.

Imms, C., Adair, B., Keen, D., Ullenhag, A., Rosenbaum, P., \& Granlund, M. (2016). 'Participation': A systematic review of language, definitions, and constructs used in intervention research with children with disabilities. Developmental Medicine and Child Neurology, 58(1), 2938. http://doi.org/10.1111/dmcn.12932

Ingo, E., Brännström, K. J., Andersson, G., Lunner, T., \& Laplante-Lévesque, A. (2016). Measuring motivation using the transtheoretical (stages of change) model: A follow-up study of people who failed an online hearing screening. International Journal of Audiology, 55(sup3), S52S58. http://doi.org/10.1080/14992027.2016.1182650

Ingo, E., Brännström, K. J., Andersson, G., Lunner, T., \& Laplante-Lévesque, A. (2017). Stages of change in audiology: comparison of three selfassessment measures. International Journal of Audiology, O(0), 1-5. http://doi.org/10.1080/14992027.2017.1309466

Jespersen, C. T., Groth, J., Kiessling, J., Brenner, B., \& Jensen, O. D. (2006). The occlusion effect in unilateral versus bilateral hearing aids. Journal of American Academic Audiology, 17(10), 763-773. http://doi.org/https://doi.org/10.3766/jaaa.17.10.7

Johansson, R., Hesser, H., Ljótsson, B., Frederick, R. J., \& Andersson, G. (2012). Transdiagnostic, affect-focused, psychodynamic, guided selfhelp for depression and anxiety through the internet: study protocol for a randomised controlled trial. BMJ Open, 2(6), 1-7. http://doi.org/10.1136/bmjopen-2012-002167

Jones, D. A., Victor, C. R., \& Vetter, N. J. (1984). Hearing difficulty and its psychological implications for the elderly. Journal of Epidemiology and Community Health, 38(1), 75-78. http://doi.org/10.1136/jech.38.1.75 
Jüris, L., Andersson, G., Larsen, H.-C., \& Ekselius, L. (2014). Cognitive behaviour therapy for hyperacusis: A randomized controlled trial. Behaviour Research and Therapy, 54, 30-37.

Kaldo, V., Levin, S., Widarsson, J., Buhrman, M., Larsen, H.-C., \& Andersson, G. (2008). Internet versus group cognitive-behavioral treatment of distress associated with tinnitus: a randomized controlled trial. Behavior Therapy, 39(4), 348-59. http://doi.org/10.1016/j.beth.2007.10.003

Karekla, M., \& Panayiotou, G. (2011). Coping and experiential avoidance: Unique or overlapping constructs? Journal of Behavior Therapy and Experimental Psychiatry, 42(2), 163-170. http://doi.org/10.1016/j.jbtep.2010.10.002

Kazdin, A. E. (2007). Mediators and mechanisms of change in psychotherapy research. Annual Review of Clinical Psychology, 3, 1-27. http://doi.org/10.1146/annurev.clinpsy.3.022806.091432

Keidser, G., \& Seeto, M. (2017). The Influence of Social Interaction and Physical Health on the Association Between Hearing and Depression With Age and Gender. Trends in Hearing, 21, 233121651770639. http://doi.org/10.1177/2331216517706395

Keidser, G., Seeto, M., Rudner, M., Hygge, S., \& Rönnberg, J. (2015). On the relationship between functional hearing and depression. International Journal of Audiology, 2027(April), 1-12. http://doi.org/10.3109/14992027.2015.1046503

Kenny, D. A. (2015). Measuring model fit. Retrieved 13 April 2018, from http://davidakenny.net/cm/fit.htm

Kickbusch, I. S. (2001). Health literacy: addressing the health and education divide. Health Promotion International, 16(3), 289-297. http://doi.org/10.1093/HEAPRO/16.3.289

Kiely, K. M., Gopinath, B., Mitchell, P., Browning, C. J., \& Anstey, K. J. (2012). Evaluating a dichotomized measure of self-reported hearing loss against gold standard audiometry: Prevalence estimates and age bias in a pooled national data set. Journal of Aging and Health, 24(3), 439-458. http://doi.org/10.1177/0898264311425088

King, R., \& Bickman, L. (2017). Is There a Future for Therapists? Administration and Policy in Mental Health and Mental Health Services Research, 44(5), 595-597. http://doi.org/10.1007/s10488-017-0814-1

Klingberg, T. (2010). Training and plasticity of working memory. Trends in Cognitive Sciences, 14(7), 317-324. http://doi.org/10.1016/j.tics.2010.05.002

Knudsen, L. V., Öberg, M., Nielsen, C., Naylor, G., \& Kramer, S. E. (2010). Factors Influencing Help Seeking, Hearing Aid Uptake, Hearing Aid Use and Satisfaction With Hearing Aids: A Review of the Literature. 
Trends in Amplification, 14(3), 127-54. http://doi.org/10.1177/1084713810385712

Kochkin, S. (2007). MarkeTrak VII: Obstacles to adult non-user adoption of hearing aids. Hearing Journal, 60(4), 24-51. http://doi.org/10.1097/01.HJ.0000285745.08599.7f

Kochkin, S. (2010). MarkeTrak VIII: Consumer satisfaction with hearing aids is slowly increasing. Hearing Journal, 63(1), 19-32. http://doi.org/10.1097/01.HJ.0000366912.40173.76

Koopman, J., Davey, E., Thomas, N., Wittkop, T., \& Verschuure, H. (2008). How should hearing screening tests be offered? International Journal of Audiology, 47(5), 230-7. http://doi.org/10.1080/14992020801908236

Kramer, S. E., Kapteyn, T. S., Festen, J. M., \& Tobi, H. (1996). The Relationships between Self-reported Hearing Disability and Measures of Auditory Disability. International Journal of Audiology, 35(5), 277287. http://doi.org/10.3109/00206099609071948

Kroenke, K., Spitzer, R. L., \& Williams, J. B. W. (2001). The PHQ-9: validity of a brief depression severity measure. Journal of General Internal Medicine, 16(9), 606-613.

Krog, N. H., Engdahl, B., \& Tambs, K. (2010). The association between tinnitus and mental health in a general population sample: results from the HUNT Study. Journal of Psychosomatic Research, 69(3), 289-98. http://doi.org/10.1016/j.jpsychores.2010.03.008

Kvam, M. H., Loeb, M., \& Tambs, K. (2007). Mental health in deaf adults: Symptoms of anxiety and depression among hearing and deaf individuals. Journal of Deaf Studies and Deaf Education, 12(1), 1-7. http://doi.org/10.1093/deafed/en1015

Laplante-Lévesque, A., Brännström, K. J., Ingo, E., Andersson, G., \& Lunner, T. (2015). Stages of Change in Adults Who Have Failed an Online Hearing Screening. Ear and Hearing, 36(1), 92-101. http://doi.org/10.1097/AUD.0000000000000085

Laplante-Lévesque, A., Hickson, L., \& Worrall, L. (2010). Rehabilitation of older adults with hearing impairment: A critical review. Journal of Aging and Health, 22(2), 143-153. http://doi.org/10.1177/0898264309352731

Larsby, B., Hällgren, M., \& Lyxell, B. (2008). The interference of different background noises on speech processing in elderly hearing impaired subjects. International Journal of Audiology, 47 Suppl 2, S83-90. http://doi.org/10.1080/14992020802301159

Lazard, D. S., Lee, H. J., Gaebler, M., Kell, C. a, Truy, E., \& Giraud, a L. (2010). Phonological processing in post-lingual deafness and cochlear implant outcome. NeuroImage, 49(4), 3443-51. http://doi.org/10.1016/j.neuroimage.2009.11.013 
Leensen, M. C. J., de Laat, J. a P. M., \& Dreschler, W. a. (2011). Speech-innoise screening tests by internet, part 1: test evaluation for noise-induced hearing loss identification. International Journal of Audiology, 50(11), 823-34. http://doi.org/10.3109/14992027.2011.595016

Lehane, C. M., Dammeyer, J., \& Wittich, W. (2017). Intra- and interpersonal effects of coping on the psychological well-being of adults with sensory loss and their spouses. Disability and Rehabilitation, O(0), 1-12. http://doi.org/10.1080/09638288.2017.1410583

Light, K. J., \& Looi, V. (2011). Reactions to the Diagnosis of a Progressive Hearing Loss in Adults. The Journal Academy of Rehabilitative Audiology.

Lindner, P., Andersson, G., Öst, L.-G., \& Carlbring, P. (2013). Validation of the Internet-Administered Quality of Life Inventory (QOLI) in Different Psychiatric Conditions. Cognitive Behaviour Therapy, (October), 3741. http://doi.org/10.1080/16506073.2013.806584

Livingston, G., Sommerlad, A., Orgeta, V., Costafreda, S. G., Huntley, J., Ames, D., ... Mukadam, N. (2017). Dementia prevention, intervention, and care. The Lancet, 390(10113), 2673-2734. http://doi.org/10.1016/S0140-6736(17)31363-6

Lunner, T. (2003). Cognitive function in relation to hearing aid use. International Journal of Audiology, 42(sup1), 49-58. http://doi.org/10.3109/14992020309074624

Malmberg, M., Lunner, T., Kähäri, K., \& Andersson, G. (2017). Evaluating the short-term and long-term effects of an internet-based aural rehabilitation programme for hearing aid users in general clinical practice: A randomised controlled trial. BMJ Open, 7(5), 1-14. http://doi.org/10.1136/bmjopen-2016-013047

Manchaiah, V. K. C., \& Stephens, D. (2012). The 'patient journey' of adults with sudden-onset acquired hearing impairment: A pilot study. Journal of Laryngology and Otology, 126(5), 475-481. http://doi.org/10.1017/S0022215111003197

Manchaiah, V. K. C., \& Stephens, D. (2013). Perspectives on defining 'hearing loss' and its consequences. Hearing, Balance and Communication, 11(1), 6-16. http://doi.org/10.3109/21695717.2012.756624

Manchaiah, V. K. C., Stephens, D., \& Meredith, R. (2011). The patient journey of adults with hearing impairment: the patients' views. Clinical Otolaryngology, 36(3), 227-34. http://doi.org/10.1111/j.17494486.2011.02320.x

McCormack, A., \& Fortnum, H. (2013). Why do people fitted with hearing aids not wear them? International Journal of Audiology, 52(5), 360-368. http://doi.org/10.3109/14992027.2013.769066 
McCracken, L. M. (1998). Learning to live with the pain: acceptance of pain predicts adjustment in persons with chronic pain. Pain, 74(1), 21-7.

McCracken, L. M., Carson, J. W., Eccleston, C., \& Keefe, F. J. (2004). Acceptance and change in the context of chronic pain. Pain, 109(1-2), 4-7. http://doi.org/10.1016/j.pain.2004.02.006

McCracken, L. M., Vowles, K. E., \& Eccleston, C. (2004). Acceptance of chronic pain: component analysis and a revised assessment method. Pain, 107(1-2), 159-166. http://doi.org/10.1016/j.pain.2003.10.012

McFarlane, L.-A. (2012). Motivational Interviewing: Practical Strategies for Speech-Language Pathologists and Audiologists. Canadian Journal of Speech-Language Pathology and Audiology, 36(1).

Meyer, C., Hickson, L., Khan, A., \& Hartley, D. (2011). Investigation of the Actions Taken by Adults Who Failed a Telephone-Based Hearing Screen. Ear and Hearing, 32(6), 720-731.

Meyer, C., Hickson, L., Lovelock, K., Lampert, M., \& Khan, A. (2014). An investigation of factors that influence help-seeking for hearing impairment in older adults. International Journal of Audiology, 53(S1). http://doi.org/10.3109/14992027.2013.839888

Mick, P., Kawachi, I., \& Lin, F. R. (2014). The association between hearing loss and social isolation in older adults. Otolaryngology - Head and Neck Surgery (United States), 150(3), 378-384. http://doi.org/10.1177/0194599813518021

Molander, P., Hesser, H., Weineland, S. M., Bergwall, K., Buck, S., HanssonMalmöf, J., ... Andersson, G. (2015). Internet-Based Acceptance and Commitment Therapy for Psychological Distress Experienced by People With Hearing Problems: Study Protocol for a Randomized Controlled Trial. American Journal of Audiology, 24(2), 307-310. http://doi.org/10.1044/2015

Morrell, C. H., Gordon-Salant, S., Pearson, J. D., Brant, L. J., \& Fozard, J. L. (1996). Age- and gender-specific reference ranges for hearing level and longitudinal changes in hearing level. The Journal of the Acoustical Society of America, 100(October 1996), 1949-1967. http://doi.org/10.1121/1.417906

Nachtegaal, J., Festen, J. M., \& Kramer, S. E. (2011). Hearing ability and its relationship with psychosocial health, work-related variables, and health care use: the National Longitudinal Study on Hearing. Audiology Research, 1(1S). http://doi.org/10.4081/audiores.2011.e9

Nachtegaal, J., Smit, J. H., Smits, C., Bezemer, P. D., van Beek, J. H. M., Festen, J. M., \& Kramer, S. E. (2009). The association between hearing status and psychosocial health before the age of 70 years: results from an internet-based national survey on hearing. Ear and Hearing, 30(3), 302-312. http://doi.org/10.1097/AUD.0b013e31819c6e01 
Nieman, C. L., \& Lin, F. R. (2017). Increasing access to hearing rehabilitation for older adults. Current Opinion in Otolaryngology \& Head and Neck Surgery, 25(5), 342-346. http://doi.org/10.1097/MOO.0000000000000386

Nondahl, D., Cruickshanks, K., Wiley, T., Tweed, T., Klein, R., \& Klein, B. (1998). Accuracy of self-reported hearing loss. Audiology, 37, 295-301.

Nordvik, Ø., Heggdal, P. O. L., Brännström, J., Vassbotn, F., Aarstad, A. K., \& Aarstad, H. J. (2018). Generic quality of life in persons with hearing loss : a systematic literature review, 1-13. http://doi.org/10.1186/s12901-018-0051-6

Nosek, B. A., Alter, G., Banks, G. C., Borsboom, D., Bowman, S. D., Breckler, S. J., ... Yarkoni, T. (2015). Promoting an open research culture. Science, 348(6242), 1422-1425. http://doi.org/10.1126/science.aab2374

Nuesse, T., Steenken, R., Neher, T., \& Holube, I. (2018). Exploring the Link Between Cognitive Abilities and Speech Recognition in the Elderly Under Different Listening Conditions, Frontiers in Psychology, 9:678. http://doi.org/10.3389/fpsyg.2018.00678

O’Donohue, W. T., \& Fisher, J. E. (2008). Cognitive Behavior Therapy: Applying Empirically Supported Techniques in Your Practice: 2nd Edition. Wiley.

O’Malley, K. J., Cook, K. F., Price, M. D., Wildes, K. R., Hurdle, J. F., \& Ashton, C. M. (2005). Measuring diagnoses: ICD code accuracy. Health Services Research, 40(5 II), 1620-1639. http://doi.org/10.1111/j.14756773.2005.00444.x

Paparella, M. M., \& Djalilian, H. R. (2002). Etiology, pathophysiology of symptoms, and pathogenesis of Meniere's disease. Otolaryngologic Clinics of North America, 35(3), 529-545. http://doi.org/10.1016/S0030-6665(02)00019-1

Pearson, J. D., Morrell, C. H., Gordon-Salant, S., Brant, L. J., Metter, E. J., Klein, L. L., \& Fozard, J. L. (1995). Gender differences in a longitudinal study of age-associated hearing loss. The Journal of the Acoustical Society of America, 97(2), 1196-1205. http://doi.org/10.1121/1.412231

Phillips, M. D., Lowe, M. J., Lurito, J. T., Dzemidzic, M., \& Mathews, V. P. (2001). Temporal lobe activation demonstrates sex-based differences during passive listening. Radiology, 220(19), 202--207. http://doi.org/10.1148/radiology.220.1.r01j134202

Pichora-Fuller, M. K., Kramer, S. E., Eckert, M. A., Edwards, B., Hornsby, B. W. Y., Humes, L. E., ... Wingfield, A. (2016). Hearing impairment and cognitive energy: The framework for understanding effortful listening (FUEL). Ear and Hearing, 37(July), 5S-27S. http://doi.org/10.1097/AUD.0000000000000312 
Pichora-Fuller, M. K., \& Singh, G. (2006). Effects of Age on Auditory and Cognitive Processing: Implications for Hearing Aid Fitting and Audiologic Rehabilitation. Trends in Amplification, 10(1), 29-59. http://doi.org/10.1177/108471380601000103

Picou, E. M., Ricketts, T. a, \& Hornsby, B. W. Y. (2013). How hearing AIDS, background noise, and visual cues influence objective listening effort. Ear and Hearing, 34(5), e52-64. http://doi.org/10.1097/AUD.0b013e31827f0431

Plack, C. J. (2010). Oxford Handbook of Auditory Science: Hearing Overview. Oxford University Press. http://doi.org/10.1093/oxfordhb/9780199233557.013.0001

Potgieter, J.-M., Swanepoel, D. W., Myburgh, H. C., Hopper, T. C., \& Smits, C. (2016). Development and validation of a smartphone-based digits-innoise hearing test in South African English. International Journal of Audiology, 2027(May),

$1-7$. http://doi.org/10.3109/14992027.2016.1172269

Prochaska, J. O., \& Di Clemente, C. C. (1982). Transtheoretical therapy: Toward a more integrative model of change. Psychotherapy, 19(3), 276288. http://doi.org/10.1037/h0088437

Pronk, M., Deeg, D. J. H., Festen, J. M., Twisk, J. W., Smits, C., Comijs, H. C., \& Kramer, S. E. (2013). Decline in older persons' ability to recognize speech in noise: the influence of demographic, health-related, environmental, and cognitive factors. Ear and Hearing, 34(6), 722-32. http://doi.org/10.1097/AUD.0b013e3182994eee

Pronk, M., Deeg, D. J. H., Smits, C., Van Tilburg, T. G., Kuik, D. J., Festen, J. M., \& Kramer, S. E. (2011). Prospective effects of hearing status on loneliness and depression in older persons: Identification of subgroups. International Journal of Audiology, 50(12), 887-896. http://doi.org/10.3109/14992027.2011.599871

Rönnberg, J. (2003). Cognition in the hearing impaired and deaf as a bridge between signal and dialogue: a framework and a model. International Journal of Audiology, 42(sup1), 68-76. http://doi.org/10.3109/14992020309074626

Rönnberg, J., Hygge, S., Keidser, G., \& Rudner, M. (2014). The effect of functional hearing loss and age on long- and short-term visuospatial memory: evidence from the UK biobank resource. Frontiers in Aging Neuroscience, 6(December), 326. http://doi.org/10.3389/fnagi.2014.00326

Rönnberg, J., Lunner, T., Ng, E. H. N., Lidestam, B., Zekveld, A. A., Sörqvist, P., ... Stenfelt, S. (2016). Hearing impairment, cognition and speech understanding: exploratory factor analyses of a comprehensive test battery for a group of hearing aid users, the $\mathrm{n} 200$ study. International 
Journal of Audiology, 55(11), 623-642. http://doi.org/10.1080/14992027.2016.1219775

Rönnberg, J., Lunner, T., Zekveld, A., Sörqvist, P., Danielsson, H., Lyxell, B., ... Rudner, M. (2013). The Ease of Language Understanding (ELU) model: theoretical, empirical, and clinical advances. Frontiers in Systems Neuroscience, $\quad 7(\mathrm{July}), \quad 1-17$. http://doi.org/10.3389/fnsys.2013.00031

Rozental, A., Magnusson, K., Boettcher, J., Andersson, G., \& Carlbring, P. (2017). For better or worse: An individual patient data meta-analysis of deterioration among participants receiving Internet-based cognitive behavior therapy. Journal of Consulting and Clinical Psychology, 85(2), 160-177. http://doi.org/10.1037/ccp0000158

Ruggles, D., Bharadwaj, H., \& Shinn-Cunningham, B. G. (2011). Normal hearing is not enough to guarantee robust encoding of suprathreshold features important in everyday communication. Proceedings of the National Academy of Sciences, 108(37), 15516-15521. http://doi.org/10.1073/pnas.1108912108

Salonen, J., Johansson, R., Karjalainen, S., Vahlberg, T., \& Isoaho, R. (2011). Relationship between self-reported hearing and measured hearing impairment in an elderly population in Finland. International Journal of Audiology, $50(5)$,

297-302. http://doi.org/10.3109/14992027.2010.549517

Schreiber, J. B., Nora, A., Stage, F. K., Barlow, E. A., King, J., Nora, A., \& Barlow, E. A. (2006). Reportig Structural Equation Modeling and Confirmatory Factor Analysis Results: A Review. The Journal of Educational Research, 232-338. http://doi.org/10.3200/JOER.99.6.323-338

Sheehan, D. V., Lecrubier, Y., Sheehan, K. H., Amorim, P., Janavs, J., Weiller, E., ... Dunbar, G. C. (1998). The Mini-International Neuropsychiatric Interview (M.I.N.I.): The development and validation of a structured diagnostic psychiatric interview for DSM-IV and ICD10. Journal of Clinical Psychiatry, 59(SUPPL. 20), 22-33. http://doi.org/10.1016/S0924-9338(99)80239-9

Shipstead, Z., Redick, T. S., \& Engle, R. W. (2012). Is working memory training effective? Psychological Bulletin, 138(4), 628-654. http://doi.org/10.1037/a0027473

Skinner, B. (1974). About Behaviorism. New York: Knopf.

Smits, C., Merkus, P., \& Houtgast, T. (2006). How we do it: The Dutch functional hearing-screening tests by telephone and internet. Clinical Otolaryngology, $31(5), \quad 436-40 . \quad \mathrm{http} / / /$ doi.org/10.1111/j.17494486.2006.01195.x

Söder, M. (2009). Tensions, perspectives and themes in disability studies. 
Scandinavian Journal of Disability Research, 11(2), 67-81. http://doi.org/10.1080/15017410902830496

Southall, K., Gagné, J.-P., \& Jennings, M. B. (2010). Stigma: a negative and a positive influence on help-seeking for adults with acquired hearing loss. International Journal of Audiology, 49(11), 804-14. http://doi.org/10.3109/14992027.2010.498447

Souza, P., Arehart, K., \& Neher, T. (2015). Working memory and hearing aid processing: Literature findings, future directions, and clinical applications. Frontiers in Psychology, 6(DEC), 1-12. http://doi.org/10.3389/fpsyg.2015.01894

Spitzer, R. L. R., Kroenke, K., Williams, J. B. W., \& Löwe, B. (2006). A brief measure for assessing generalized anxiety disorder: the GAD-7. Archives of Internal Medicine, 166(10), 1092-7. http://doi.org/10.1001/archinte.166.10.1092

Stam, M., Smits, C., Twisk, J. W. R., Lemke, U., Festen, J. M., \& Kramer, S. E. (2015). Deterioration of Speech Recognition Ability Over a Period of 5 Years in Adults Ages 18 to 70 Years. Ear and Hearing, 36(3), e129e137. http://doi.org/10.1097/AUD.0000000000000134

Strawbridge, W. J., Wallhagen, M. I., Shema, S. J., \& Kaplan, G. A. (2000). Negative Consequences of Hearing Impairment in Old Age: A Longitudinal Analysis. The Gerontologist, 40(3), 320-326.

Strelnikov, K., Rouger, J., Lagleyre, S., Fraysse, B., Deguine, O., \& Barone, P. (2009). Improvement in speech-reading ability by auditory training: Evidence from gender differences in normally hearing, deaf and cochlear implanted subjects. Neuropsychologia, 47(4), 972-979. http://doi.org/10.1016/j.neuropsychologia.2008.10.017

Ström, M., Uckelstam, C.-J., Andersson, G., Hassmén, P., Umefjord, G., \& Carlbring, P. (2013). Internet-delivered therapist-guided physical activity for mild to moderate depression: a randomized controlled trial. PeerJ, 1, e178. http://doi.org/10.7717/peerj.178

Sundewall Thorén, E., Öberg, M., Wänström, G., Andersson, G., \& Lunner, T. (2014). A randomized controlled trial evaluating the effects of online rehabilitative intervention for adult hearing-aid users. International Journal of Audiology, (November 2013), 1-10. http://doi.org/10.3109/14992027.2014.892643

Swanepoel, D. W., \& Hall, J. W. (2010). A Systematic Review of Telehealth Applications in Audiology. Telemedicine and E-Health, 16(2), 181-200. http://doi.org/10.1089/tmj.2009.0111

Tambs, K. (2004). Moderate Effects of Hearing Loss on Mental Health and Subjective Well-Being : Results From the Nord-Trøndelag Hearing Loss Study. Psychosomatic Medicine, 66(5), 776-782. http://doi.org/10.1097/01.psy.0000133328.03596 
Tao, L., \& Taft, M. (2017). Influences of Cognitive Processing Capacities on Speech Perception in Young Adults. Frontiers in Psychology, 8(March). http://doi.org/10.3389/fpsyg.2017.00266

Theunissen, M., Swanepoel, D. W., \& Hanekom, J. (2009). Sentence recognition in noise: Variables in compilation and interpretation of tests. International Journal of Audiology, 48(11), 743-57. http://doi.org/10.3109/14992020903082088

Thodi, C., Parazzini, M., Kramer, S. E., Davis, A., Stenfelt, S., Janssen, T., ... Grandori, F. (2013). Adult Hearing Screening: Follow-Up and Outcomes. American Journal of Audiology, 22(June 2013), 183-185. http://doi.org/10.1044/1059-0889(2013/12-0060)American

Titov, N., Dear, B., \& Rapee, R. (2013). New horizons for e-mental health research and practice. Australian and New Zealand Journal of Psychiatry, 47(2), 107-108. http://doi.org/10.1177/0004867412470011

Ventry, I. M., \& Weinstein, B. E. (1982). The Hearing Handicap Inventory for the Elderly. Ear and Hearing, 3(3), 128-134. http://doi.org/10.1097/00003446-198205000-00006

Viane, I., Crombez, G., Eccleston, C., Poppe, C., Devulder, J., Van Houdenhove, B., \& De Corte, W. (2003). Acceptance of pain is an independent predictor of mental well-being in patients with chronic pain: Empirical evidence and reappraisal. Pain, 106(1-2), 65-72. http://doi.org/10.1016/S0304-3959(03)00291-4

Vilardaga, R., Hayes, S. C., \& Levin, M. E. (2009). Creating a Strategy for Progress : A Contextual Behavioral Science Approach, 1(1), 105-133.

Vlaming, M., \& Houtgast, T. (2010). Hearing in the Communication Society. Wagner, P. J., \& Curran, P. (1984). Health beliefs and physician identified 'worried well.' Health Psychology, 3(5), 459-474. http://doi.org/10.1037/0278-6133.3.5.459

Waller, G. (2009). Evidence-based treatment and therapist drift. Behaviour Research and Therapy, 47(2), 119-127. http://doi.org/10.1016/j.brat.2008.10.018

Wallhagen, M. I. (2010). The stigma of hearing loss. Gerontologist, 50(1), 66-75. http://doi.org/10.1093/geront/gnp107

Wayne, R. V., Hamilton, C., Huyck, J. J., \& Johnsrude, I. S. (2016). Working memory training and speech in noise comprehension in older adults. Frontiers in Aging Neuroscience, 8(MAR), 1-15. http://doi.org/10.3389/fnagi.2016.00049

Wayne, R. V., \& Johnsrude, I. S. (2015). A review of causal mechanisms underlying the link between age-related hearing loss and cognitive decline. Ageing Research Reviews, 23, 154-166. http://doi.org/10.1016/j.arr.2015.06.002

Weineland, S. M., Andersson, G., Lunner, T., Carlbring, P., Hesser, H., Ingo, 
E., ... Laplante-Lévesque, A. (2015). Bridging the Gap Between Hearing Screening and Successful Rehabilitation: Research Protocol of a Randomized Controlled Trial of Motivational Interviewing via Internet. American Journal of Audiology, 24(3), 302-306. http://doi.org/10.1044/2015

Westin, V., Hayes, S. C., \& Andersson, G. (2008). Is it the sound or your relationship to it? The role of acceptance in predicting tinnitus impact. Behaviour Research and Therapy, 46(12), 1259-65. http://doi.org/10.1016/j.brat.2008.08.008

Whitton, J. P., Hancock, K. E., Shannon, J. M., Polley, D. B., Whitton, J. P., Hancock, K. E., ... Polley, D. B. (2017). Audiomotor Perceptual Training Enhances Speech Intelligibility in Background Noise Article Audiomotor Perceptual Training Enhances Speech Intelligibility in Background Noise. Current Biology, 1-11. http://doi.org/10.1016/j.cub.2017.09.014

WHO. (2001). International Classification of Functioning, Disability and Health (ICF). Geneva: WHO.

WHO. (2004). International statistical classification of diseases and related health problems. Geneva: WHO.

Wicksell, R. K., Ahlqvist, J., Bring, A., Melin, L., \& Olsson, G. L. (2008). Can Exposure and Acceptance Strategies Improve Functioning and Life Satisfaction in People with Chronic Pain and Whiplash-Associated Disorders (WAD)? A Randomized Controlled Trial. Cognitive Behaviour Therapy, 37(3), 169-182. http://doi.org/10.1080/16506070802078970

Williams, K. C., Falkum, E., \& Martinsen, E. W. (2015). Fear of negative evaluation, avoidance and mental distress among hearing-impaired employees. Rehabilitation Psychology, 60(1), 51-58. http://doi.org/10.1037/rep0000028

Wilson, B. S., Tucci, D. L., Merson, M. H., \& O'Donoghue, G. M. (2017). Global hearing health care: new findings and perspectives. The Lancet, 390(10111), 2503-2515. http://doi.org/10.1016/S0140-6736(17)310735

Wilson, \& Jungner, G. (1968). Principles and Practice of Screening for Disease. Public Health Papers. Geneva: World Health Organization. http://doi.org/10.1001/archinte.1969.00300130131020

Wingfield, A., \& Tun, P. a. (2007). Cognitive Supports and Cognitive Constraints on Comprehension of Spoken Language. J Am Acad Audiol, 558(2007), 548-558.

Yamasoba, T., Lin, F. R., Someya, S., Kashio, A., Sakamoto, T., \& Kondo, K. (2013). Current concepts in age-related hearing loss: epidemiology and mechanistic pathways. Hearing Research, 303, 30-8. 
http://doi.org/10.1016/j.heares.2013.01.021

Yueh, B., Collins, M. P., Souza, P. E., Boyko, E. J., Loovis, C. F., Heagerty, P. J., ... Hedrick, S. C. (2010). Long-term effectiveness of screening for hearing loss: the screening for auditory impairment--which hearing assessment test (SAI-WHAT) randomized trial. Journal of the American Geriatrics Society, 58(3), 427-34. http://doi.org/10.1111/j.15325415.2010.02738.x

Zeng, F.-G., \& Djalilian, H. (2010). Hearing impairment. Oxford University Press. http://doi.org/10.1093/oxfordhb/9780199233557.013.0014

Zhao, X., Lynch, J. G., \& Chen, Q. (2010). Reconsidering Baron and Kenny: Myths and Truths about Mediation Analysis. Journal of Consumer Research, 37(2), 197-206. http://doi.org/10.1086/651257 


\section{Acknowledgments}

Klyschan säger att det krävs en hel by för att uppfostra ett barn. I mitt fall verkar det krävas tre universitetsavdelningar för att uppfostra en doktorand. Det finns därför all anledning att rikta tacksamhet mot många som alla på olika sätt möjliggjort för mig att skriva den här avhandlingen. Först måste jag dock börja med det allra viktigaste: ett stort tack till alla deltagare! Totalt var ni 2207 stycken individer som deltagit i studierna. Utan er, ingen avhandling. Jag hoppas innerligt att ni alla, på något sätt, får uppleva lite nytta för ansträngningarna ni gjort.

Inom ramen för HEAD forskarskola har doktorandstudierna bedrivits. Ett stort tack är på sin plats, för flexibilitet med att ha låtit mig genomföra studierna på ett sätt som passat mig och för allt jag lärt mig i kurserna. Särskilt vill jag uppmärksamma Emil, Håkan och Jakob som förgyllde läsandet av baskurser i början av doktorandstudierna.

På avdelning för psykologi har jag i praktiken suttit under doktorandtiden. Där finns också min huvudhandledare Gerhard. Redan innan jag blev doktorand lärde du mig om hur kul forskning kan vara och visade mer tilltro till min förmåga än vad jag själv hade. Utan det tror jag inte att en seriös tanke på att doktorera ens hade slagit mig. Genom åren har jag haft förmånen att kunna ta till mig av råd och erfarenheter du gjort och lärt mig mer hur man navigerar mellan det ideala och det möjliga på ett sätt nog ingen utan all din erfarenhet av behandlingsforskning kunnat bidra med. Det går inte heller att överdriva hur viktigt det varit för mig att det gått att ha roliga samtal om stort och smått, förutom ändlös uppmuntran och föregångsmannaskap.

Min bihandledare Hugo finns också på avdelningen för psykologi. Tack för allt. För att jag fătt störa dig otaliga gånger per dag med frågor. För att du tagit dig tid att förklara sådant jag tyckte (och tycker!) är svårt. För att du så noggrant läst vad jag skrivit. För all hjälp med att hitta rätt i svåra situationer, både sådant som relaterar till forskning och annat. För lunchsällskap. För att du varit min vän.

Thomas har också varit min bihandledare. Alltid uppmuntrande, snabb i tanken och en förmåga att ställa rätt frågor som jag själv varit blind för. 
Dessutom alltid med en relevant referens i skjortärmen, och leverantör av den bästa sortens pennor. Tack!

På avdelning för psykologi finns också flertalet som ingår, eller har ingått, i forskargruppen. Med er har det diskuterats, hjälpts till, fikats och bollats idéer om allt det där som är så viktigt men som man inte kan hitta i en kursplan. Tack till Ingo för gott samarbete, hjälp med att räta ut vända skalor, audiologin som ämne, ärtor, delad frustration och användbara kommentarer. Robert $\mathbf{J}$ för insikterna kring hur viktigt det är att välja tidskrift efter hur snygga artiklarna blir i tryck. Vendela för att vara så välkomnande när jag som mest behövde det. Sandra för allt arbete med utformning och studenthandledande till behandlingen. Jesper och Robert PA för att ni varit så förbaskat trevliga. Särskilt tack också till NT för hjälp med jobb, kamrathandledning och spännande historier om allt från brinnande gasbehållare till antika cykelkomponenter. Tack också till Alexander som hittar på användbara skalor och bidragit med gott resesällskap. Slutligen, tack till barnbordet (ingen nämnd, ingen glömd).

Särskilt måste jag säga tack till George. Utan ditt tekniska kunnande, intensiva arbetstakt och förmåga att uppmärksamma sådant man själv inte tänkt på hade behandlingen helt enkelt inte gått att genomföra. Jag vill också passa på att säga tack till Maria och Lise, inte för att ni sett till att jag varit med och fikat (vilket varit nog så viktigt) utan för det djupa kliniska kunnandet. Alltid med goda råd, alltid med en förmåga att möta på den nivå man befinner sig.

Den tredje avdelningen som jag haft förmånen att lära mig kring hur man bedriver forskning och utbildning från är forskningsavdelningen på Smärtoch rehabiliteringsenheten. Vad som började med en förbipasserande fråga om jag kunde SPSS har lett fram till att jag haft förmånen att ingå $\mathrm{i}$ projektledningsmöten och fått överblick över hur forskararbetet bedrivs i en helt annan miljö, har fått författa artiklar på data med tiotusentals deltagare, utforma och bedriva behandlingsforskning och ingå i nationella forskarnätverk. Jag har också fått ett helt gäng vänner och doktorandkollegor på det sättet, Martin, Marie, Nina och Tobias (och Nicco). Allt detta trots att 
jag varit anställd som kliniker och inte forskare! Denna ynnest är få förunnat, och hade inte gått utan att Björn varit så generös. Tack Björn!

Det är dock inte bara arbetsmiljöerna som krävts för att kunna genomföra det här avhandlingsarbetet. Först av allt måste jag säga tack till Lisa för all hjälp genom åren. Du har uppmuntrat, förstått, avlastat och hjälpt mig tänka när jag som mest behövt det. Inget av det här hade gått utan dig. Också tack till Maja för att du sett till att jag fått struktur på dagen, miljöombyte, motion och obegränsat med uppskattning. Förstås också tack till Stellan för en ny sorts glädje i livet!

Ett tack till Micke är också på sin plats, för utan att det hade varit så kul att skriva examensarbete ihop hade jag nog inte velat fortsätta med forskningsspåret. Tack också till dig och Becca för mikrovågsugnslasagne, vänskap, turer till Västmanlands pärla, mässing och stilinspiration. Igen, också tack till Tobias och Nicco för fin vänskap, trevliga arbetsdagar, goda middagar och samtal om vaxproppar. Även Per förtjänar ett tack, för långvarig vänskap, för att ha visat vad som är möjligt och för att alltid se till att man är på bra humör efter att ha träffats.

Slutligen, tack också till Ante för 30 års vänskap, för att du väglett, stått ut, underhållit och funnits där som en trygg punkt igenom allt. Ibland tätt, ibland glest, alltid uppskattat. 
Studies from the Swedish Institute for Disability Research

1. Varieties of reading disability

Stefan Gustafson

ISBN 91-7219-867-2, 2000

2. Cognitive functions in drivers with brain injury - anticipation and adaptation

Anna Lundqvist

ISBN 91-7219-967-9, 2001

3. Cognitive deafness

Ulf Andersson

ISBN 91-7373-029-7, 2001

4. Att lära sig leva med förvärvad hörselnedsättning sett ur parperspektiv

Carin Fredriksson

ISBN 91-7373-105-6, 2001

5. Signs, Symptoms, and Disability Related to the Musculo-Skeletal System

Gunnar Lundberg

ISBN 91-7373-160-9, 2002

6. Participation - Ideology and Everyday Life

Anette Kjellberg

ISBN 91-7373-371-7, 2002 
7. Föräldrar med funktionshinder - om barn, föräldraskap och familjeliv

Marie Gustavsson Holmström

ISBN 91-7203-500-5, 2002

8. Active wheelchair use in daily life

Kersti Samuelsson

ISBN 91-7373-196-X, 2002

9. Två kön eller inget alls. Politiska intentioner och vardagslivets realiteter i den

arbetslivsinriktade rehabiliteringen

Marie Jansson

ISBN 91-7373-568-X, 2003

10. Audiological and cognitive long-term sequelae from closed head injury

Per-Olof Bergemalm

ISBN 91-7668-384-2, 2004

11. Att vara i särklass - om delaktighet och utanförskap i gymnasiesärskolan

Martin Molin

ISBN 91-85295-46-9, 2004

12. Rättvis idrottsundervisning för elever med rörelsehinder dilemma kring omfördelning och erkännande

Kajsa Jerlinder

Licentiate Degree, 2005 
13. Hearing impairment and deafness. Genetic and environmental factors - interactions - consequences. A clinical audiological approach

Per-Inge Carlsson

ISBN 91-7668-426-1, 2005

14. Hearing and cognition in speech comprehension. Methods and applications

Mathias Hällgren

ISBN 91-85297-93-3, 2005

15. Living with deteriorating and hereditary disease: experiences over ten years of persons with muscular dystrophy and their next of kin

Katrin Boström

ISBN 91-7668-427-x, 2005

16. Disease and disability in early rheumatoid arthritis Ingrid Thyberg

ISBN 91-85299-16-2, 2005

17. "Varför får jag icke följa med dit fram?" Medborgarskapet och den offentliga debatten om dövstumma och blinda 1860-1914 Staffan Bengtsson

ISBN 91-85457-06-X, 2005

18. Modalities of Mind. Modality-specific and nonmodality-specific aspects of working memory for sign and speech Mary Rudner

ISBN 91-85457-10-8, 2005

19. Facing the Illusion Piece by Piece. Face recognition for persons with learning disability 
Henrik Danielsson

ISBN 91-85497-09-6, 2006

20. Vuxna med förvärvad traumatisk hjärnskada omställningsprocesser och konsekvenser i vardagslivet. En studie av femton personers upplevelser och erfarenheter av att leva med förvärvad traumatisk hjärnskada

Thomas Strandberg

ISBN 91-7668-498-9, 2006

21. Nycklar till kommunikation. Kommunikation mellan vuxna personer med grav förvärvad hjärnskada och personernas närstående, anhöriga och personal

Pia Käcker

ISBN 978-91-85715-88-6, 2007

22. "Aspergern, det är jag". En intervjustudie om att leva med Asperger syndrom

Gunvor Larsson Abbad

ISBN 978-91-85831-43-2, 2007

23. Sounds of silence - Phonological awareness and written language in children with and without speech

Janna Ferreira

ISBN 978-91-85895-74-8, 2007

24. Postponed Plans: Prospective Memory and Intellectual Disability

Anna Levén

ISBN 978-91-85895-57-1, 2007

25. Consequences of brain tumours from the perspective of the patients and of their next of kin 
Tanja Edvardsson

ISBN 978-91-7668-572-3, 2008

26. Impact on participation and service for persons with deafblindness

Kerstin Möller

ISBN 978-91-7668-595-2, 2008

27. Approaches to Audiological Rehabilitation with Hearing Aids: studies on prefitting strategies and assessment of outcomes Marie Öberg

ISBN 978-91-7393-828-0, 2008

28. Social Interaction and Participation in Activities of Everyday Life Among Persons with Schizophrenia

Maria Yilmaz

Licentiate Degree, 2009

29. Focus on Chronic Disease through Different Lenses of Expertise Towards Implementation of Patient-Focused Decision Support Preventing Disability: The example of Early Rheumatoid Arthritis

Örjan Dahlström

ISBN 978-91-7393-613-2, 2009

30. Children with Cochlear Implants: Cognition and Reading

Ability

Malin Wass

ISBN: 978-91-7393-487-9, 2009

31. Restricted participation: Unaccompanied children in interpreter-mediated asylum hearings in Sweden

Olga Keselman

ISBN: 978-91-7393-499-2, 2009 
32. Deaf people and labour market in Sweden.

Education - Employment - Economy

Emelie Rydberg

ISBN: 978-91-7668-725-3, 2010

33. Social rättvisa i inkluderande idrottsundervisning

för elever med rörelsehinder - en utopi?

Kajsa Jerlinder

ISBN: 978-91-7668-726-0, 2010

34. Erfarenheter av rehabiliteringsprocessen mot ett arbetsliv

- brukarens och de professionellas perspektiv

Helene Hillborg

ISBN: 978-91-7668-741-3, 2010

35. Knowing me, knowing you - Mentalization abilities of children who use augmentative and alternative communication

Annette Sundqvist

ISBN: 978-91-7393-316-2, 2010

36. Lärare, socialsekreterare och barn som far illa - om sociala representationer och interprofessionell samverkan

Per Germundsson

ISBN: 978-91-7668-787-1, 2011

37. Fats in Mind

Effects of Omega-3 Fatty Acids on Cognition and Behaviour in

Childhood

Ulrika Birberg Thornberg

ISBN: 978-91-7393-164-9, 2011

38. "Jobbet är kommunikation" 
Om användning av arbetshjälpmedel för personer med hörselnedsättning

Sif Bjarnason

Licentiate Degree. ISBN: 978-91-7668-835-9, 2011

39. Applying the ICF-CY to identify everyday life situations of children and youth with disabilities

Margareta Adolfsson

ISBN: 978-91-628-8342-3, 2011

40. Tinnitus - an acceptance-based approach

Vendela Zetterqvist

ISBN: 978-91-7393-040-6, 2011

41. Applicability of the ICF-CY to describe functioning and environment of children with disabilities

Nina Klang

ISBN: 978-91-7668-864-9, 2012

42. Bringing more to participation

Participation in school activities of persons with Disability within the framework of the International Classification of Functioning, Disability and Health for Children and Youth (ICF-CY)

Gregor Maxwell

ISBN: 978-91-628-8484-0, 2012

43. From Eye to Us.

Prerequisites for and levels of participation in mainstream school of persons with Autism Spectrum Conditions

Marita Falkmer

ISBN: 978-91-637-2091-8, 2013

44. Otosclerosis, clinical long-term perspectives 
Ylva Dahlin-Redfors

ISBN 978-91-628-8617-2, 2013

45. Tinnitus in Context - A Contemporary Contextual Behavioral Approach

Hugo Hesser

ISBN 978-91-7519-701-2, 2013

46. Hearing and middle ear status in children and young adults with cleft palate

Traci Flynn

ISBN 978-91-628-8645-5, 2013

47. Utrymme för deltagande, beslutsprocesser i möten mellan patienter med ospecifika ländryggsbesvär och sjukgymnaster $i$ primär vård

Iréne Josephson

ISBN 42-978-91-85835-41-6, 2013

48. "Man vill ju klara sig själv" Studievardagen för studenter med Asperger syndrom i högre studier

Ann Simmeborn Fleischer

ISBN 978-91-628-8681-3, 2013

49. Cognitive erosion and its implications in Alzheimer's disease

Selina Mårdh

ISBN 978-91-7519-621-1, 2013

50. Hörselscreening av en population med utvecklingsstörning Utvärdering av psykoakustisk testmetod och av OAEregistrering som komplementär metod

Eva Andersson 
Licentiate Degree. ISBN 978-91-7519-616-9, 2013

51. Skolformens komplexitet - elevers erfarenheter av skolvardag och tillhörighet i gymnasiesärskolan

Therése Mineur

ISBN 978-91-7668-951-6, 2013

52. Evaluating the process of change:

Studies on patient journey, hearing disability acceptance and stages-of-change

Vinaya Kumar Channapatna Manchaiah

ISBN 978-91-7519-534-6, 2013

53. Cognition in hearing aid users: Memory for everyday speech

Hoi Ning (Elaine) $\mathrm{Ng}$

ISBN 978-91-7519-494-3, 2013

54. Representing sounds and spellings Phonological decline and compensatory working memory in acquired hearing impairment Elisabet Classon

ISBN 978-91-7519-500-1, 2013

55. Assessment of participation in people with a mild intellectual disability

Patrik Arvidsson

ISBN 978-91-7668-974-5, 2013

56. Barnperspektiv i barnavårdsutredningar - med barns hälsa och barns upplevelser i fokus

Elin Hultman

ISBN 978-91-7519-457-8, 2013

57. Internet Interventions for Hearing Loss 
Examining rehabilitation Self-report measures and Internet use in hearing-aid users

Elisabet Sundewall Thorén

ISBN 978-91-7519-423-3, 2014

58. Exploring Cognitive Spare Capacity: Executive Processing of Degraded Speech

Sushmit Mishra

ISBN 978-91-7519-386-1, 2014

59. Supported employment i en svensk kontext - förutsättningar när personer med funktionsnedsättning når, får och behåller ett arbete

Johanna Gustafsson

ISBN 978-91-7529-012-6, 2014

60. Effects of Specific Cochlear Pathologies on the Auditory Functions: Modelling, Simulations and Clinical Implications Amin Saremi

ISBN 978-91-7519-365-6, 2014

61. Children with profound intellectual and multiple disabilities and their participation in family activities

Anna Karin Axelsson

ISBN 978-91-85835-48-5, 2014

62. Lexical and Semantic Development in Children With Cochlear Implants

Ulrika Löfkvist

ISBN 978-91-7549-546-0, 2014 
63. Rethinking sound. Computer-assisted reading intervention with a phonics approach for deaf and hard of hearing children using cochlear implants or hearing aids

Cecilia Nakeva von Mentzer

ISBN 978-91-7519-270-3, 2014

64. Assessing cognitive spare capacity as a measure of listening effort using the Auditory Inference Span Test

Niklas Rönnberg

ISBN 978-91-7519-267-3, 2014

65. Employees with Aided Hearing Impairment: An

Interdisciplinary Perspective

Håkan Hua

ISBN 978-91-7519-240-6, 2014

66. Prosthetic and Orthotic Services in Developing Countries

Lina Magnusson

ISBN 978-91-85835-55-3, 2014

67. Dealing with digits - Arithmetic, memory and phonology in deaf signers

Josefine Andin

ISBN: 978-91-7519-235-2, 2014

68. Time is of the essence in speech recognition: Get it fast or think about it

Shahram Moradi

ISBN: 978-91-7519-188-1, 2014

69. Effects of hearing loss on traffic safety and mobility 
Birgitta Thorslund

ISBN: 978-91-7519-178-2, 2014

70. Aspekter på lärande vid dövblindhet - möjligheter och begränsningar för personer med Alström syndrom

Berit Rönnåsen

Licentiate Degree. ISBN: 978-91-7529-068-3, 2015

71. Memory and communication in typically developing infants and children with Autism Spectrum Disorder: Behavioral and electrophysiological indices

Emelie Nordqvist

ISBN: 978-91-7519-078-5, 2015

72. Cognitive capacities and composite cognitive skills in individuals with Usher syndrome type 1 and 2

Cecilia Henricson

ISBN: 978-91-7685-999-5, 2015

73. Functioning and Disability in Adults with Hearing Loss

Preparatory studies in the ICF Core Sets for Hearing Loss project

Sarah Granberg

ISBN: 978-91-7529-086-7, 2015

74. Speech recognition and memory processes in native and nonnative language perception

Lisa Kilman

ISBN: 978-91-7685-972-8, 2015

75. To include or not to include: Teachers' social representations of inclusion of students with Asperger diagnosis 
Ann-Charlotte Linton

ISBN: 978-91-7685-956-8, 2015

76. Health and People with Usher syndrome

Moa Wahlqvist

ISBN: 978-91-7529-098-0, 2015

77. Children with mild intellectual disability and their families needs for support, service utilisation and experiences of support

Lena Olsson

ISBN: 978-91-85835-66-9, 2016

78. Deafblindness

Theory-of-mind, cognitive functioning and social network in

Alström syndrome

Hans-Erik Frölander

ISBN: 978-91-7529-132-1, 2016

79. Signs for Developing Reading

Sign Language and Reading Development in Deaf and Hard-of-

Hearing Children

Emil Holmer

ISBN: 978-91-7685-767-0, 2016

80. Speech masking speech in everyday communication

The role of inhibitory control and working memory capacity

Victoria Stenbäck

ISBN: 978-7685-604-8, 2017 
81. Neural and Cognitive Effects of Hearing Loss on Speech Processing

Eline Borch Petersen

ISBN: 978-91-7685-640-6, 2017

82. A biopsychosocial approach to functioning, oral health and specialist dental health care in children with disabilities Swedish and international perspectives

Johanna Norderyd

ISBN: 978-91-85835-81-2, 2017

83. Samverkansprojekt, och sen då? - en uppföljande studie av samverkansprocessen kring barn och unga som far illa eller riskerar att fara illa

Ulrika Englund

ISBN: 978-91-7529-194-9, 2017

84. Aural rehabilitation programs for hearing aid users

Evaluating and clinically applying educational programs, supported via telephone and/or the internet and professionally guided by an audiologist

Milijana Malmberg

ISBN: 978-91-629-0187-5, 2017

85. Tolkning vid förmedlade samtal via Bildtelefoni.net

- interaktion och gemensamt meningsskapande

Camilla Warnicke

ISBN: 978-91-7529-197-0, 2017

86. Vardagslivets aktiviteter. Handlingen som terapeutiskt redskap för personer med svårare psykiska funktionshinder - Analys av arbetsterapeuters berättelser med utgångspunkt i G H Meads teori om social handling 
Marianne Boström

ISBN: 978-91-7529-206-9, 2017

87. Creative disability classification systems: The case of Greece, 1990-2015

Antonia Pavli

ISBN: 978-91-7529-204-5, 2017

88. Ej utgiven

89. Perception of disturbing sounds

Investigations of people with hearing loss and normal hearing

Åsa Skagerstrand

ISBN: 978-91-7529-229-8, 2018

90. Peer Interaction in Preschool: Necessary, but not Sufficient The Influence of Social Interaction on the Link between Behaviour Difficulties and Engagement among Children with and without Need of Special Support

Madeleine Sjöman

ISBN: 978-91-88339-13-3, 2018

91. Prosodic and Phonological Ability in Children with Developmental Language Disorder and Children with Hearing Impairment In the context of Word and Nonword Repetition Simon Sundström

ISBN: 978-91-7685-321-4, 2018 



\section{Articles}

The articles associated with this thesis have been removed for copyright reasons. For more details about these see:

http://urn.kb.se/resolve?urn=urn:nbn:se:liu:diva-152429 